\title{
Green Preparation of PtRu and PtCu/SBA-15 Catalysts using Supercritical $\mathrm{CO}_{2}$
}

E. Sánchez-Miguel, M.J. Tenorio, J. Morère and A. Cabañas*

Departamento de Química-Física I, Universidad Complutense de Madrid, 28040 Madrid. SPAIN

*Send correspondence to:

Prof. Albertina Cabañas

Departamento de Química-Física I

Ciudad Universitaria s/n, 28040 Madrid SPAIN

Tlf: $\quad 34+913945225 \quad$ Fax: $\quad 34+913944135$

e-mail: $\quad$ a.cabanas@quim.ucm.es

Keywords: Supercritical fluids, Nanoparticles, Platinum, Supported Catalysts, Hydrogenation 


\section{ABSTRACT}

Sustainability is emerging as design criteria in catalysts production. Hence, the preparation of Pt bimetallic catalysts using supercritical $\mathrm{CO}_{2}\left(\mathrm{scCO}_{2}\right)$ as a green solvent is proposed. $\mathrm{PtRu}$ and $\mathrm{PtCu}$ nanoparticles (NPs) were deposited on mesoporous $\mathrm{SiO}_{2} \mathrm{SBA}-15$ by the reduction of $\mathrm{Pt}, \mathrm{Ru}$ and $\mathrm{Cu}$ metalorganic precursor in $\mathrm{scCO}_{2}$. The simultaneous and sequential deposition of both metals was attempted using different reduction methodologies. The materials were characterized by X-Ray Diffraction (XRD), Transmission Electron Microscopy (TEM) and Energy-Dispersive X-ray analysis (EDX). XRD patterns matched closely that of cubic Pt. TEM images showed small NPs homogeneously distributed throughout the SBA-15 mesopores. Smaller particles were obtained when the reduction was performed in $\mathrm{H}_{2} / \mathrm{N}_{2}$ at low pressure. Sequential deposition of $\mathrm{Cu}$ or $\mathrm{Ru}$ in the first place followed by $\mathrm{Pt}$ yielded equimolar metal ratios. Samples prepared by sequential deposition were studied by Scanning Transmission Electron Microscopy (STEM). Composition profiles of the PtRu samples suggested an alloy structure. These catalysts were used in the hydrogenation of the renewable furfural in $\mathrm{scCO}_{2}$ at $80^{\circ} \mathrm{C}$. PtRu materials presented a high activity and selectivity to furfuryl alcohol. 


\section{INTRODUCTION}

Catalysts are essential in green chemistry research to reduce toxicity and increase chemical reactions efficiency aiming for a sustainable development [1]. In particular, the catalytic hydrogenation of organic molecules is of great importance in the pharmaceutical, petrochemical and food industries. From a green chemistry viewpoint, using molecular hydrogen increases the atom economy and at the same time it is considered a renewable feedstock. Common hydrogenation catalysts are formed by $\mathrm{Ni}$, Pd or Pt supported nanoparticles (NPs). These materials generally lead to very high activities. Other metals such as $\mathrm{Ru}$ or $\mathrm{Cu}$ are used when a high selectivity to intermediate forms or other interesting products is sought. Bimetallic catalysts can show improved properties in comparison to monometallic catalysts. The presence of two metals changes the electronic structure of the system and may alter the activity and selectivity of the catalysts [2]. In the case of expensive noble metals, the addition of a cheaper metal also offers economic advantages. Finally, controlling the metal distribution on the NP (alloy structure, raspberry, core-shell,...), the catalytic activity can be also changed.

Supported bimetallic NPs can be produced following conventional techniques such as wet impregnation of the metal precursors followed by thermal or chemical reduction[3-5], electroless deposition [6] and Chemical Vapour Deposition (CVD) [4]. Colloidal [7] and reverse micelle [8] synthesis in which preformed nanoparticles are introduced into the support are also currently used. Some of these methods offer the possibility to perform a sequential or simultaneous deposition of the metals $[3,5]$. Furthermore, for the simultaneous preparation, a

mixture of metal precursors or a bimetallic precursor can be used [9]. When the deposition of each metal is performed sequentially, several techniques can be combined [10]. 
If the process is carried out in a liquid solvent, the large viscosity and surface tension of most liquid solvents may cause the slow diffusion of the metal precursor or metal nanoparticles within the support pores leading to poorly dispersed and non-homogeneous materials. The drying process may also cause structural changes into the catalyst with a significant reduction of the support surface area and catalytic activity. On the other hand, gas phase processes such as CVD are generally limited by the low vapour pressure of the metal precursors and may not be suitable for preparation of homogeneous bimetallic materials with high metal loadings. Therefore conventional methods may lead to inhomogeneous materials of not well defined composition and structure and a broad particle size distribution. Moreover, some of these methods require the use of toxic solvents and or reagents and are multistep processes.

Supercritical $\mathrm{CO}_{2}\left(\mathrm{scCO}_{2}\right)$ has been proposed as a green solvent in the catalysts preparation following the Supercritical Fluid Deposition (SCFD) technique [11]. $\mathrm{CO}_{2}$ used is obtained as a sub-product of many industrial processes, and there is large interest in its utilization. The $\mathrm{CO}_{2}$ moderate critical temperature and pressure $\left(T_{\mathrm{c}}=31.0^{\circ} \mathrm{C}, P_{\mathrm{c}}=7.38 \mathrm{MPa}\right)$ [12], its non-toxicity and non-flammability turn it into an excellent candidate to replace toxic organic solvents. Furthermore it is a gas at atmospheric pressure and does not leave any residue. The low viscosity, high diffusivity and very low surface tension of supercritical $\mathrm{CO}_{2}$ and its high solvating power favour the penetration of metal precursors dissolved in $\mathrm{scCO}_{2}$ within the catalyst support and at the same time avoid damage in the pore structure. The impregnated support is then reduced leading to metal NPs dispersed on the support. Different metals or metal oxides nanoparticles have been deposited on organic and inorganic substrates using $\mathrm{scCO}_{2}$ [12-14]. Nanoparticle size distribution depends on concentration, reduction 
methodology and substrate [15]. Controlling the size, composition and morphology of the nanoparticles, their catalytic activity and selectivity can be tuned [16].

The deposition of bimetallic NPs onto different supports has been also addressed and reviewed by Bozbag and Erkey [14]. Supported metal NPs of PtRu, PtPd, PtCu, PtNi and $\mathrm{PtAu}$, have been previously prepared using $\mathrm{scCO}_{2}$. Apart from a very recent report by Qiao et al. on the deposition of PtPd NPs on mesoporous $\mathrm{SiO}_{2}$ supports [17], bimetallic Pt NPs were deposited on carbon based supports such as carbon nanotubes (CNTs) [14, 18, 19], carbon black [14] and, recently, on functionalized graphene sheets [20] for catalytic applications. Lang et al. have also reported the preparation of $\mathrm{PtCuO} / \mathrm{CeO}_{2} / \alpha-\mathrm{Al}_{2} \mathrm{O}_{3}$ catalysts [21]. $\mathrm{Pt} / \mathrm{SnO}_{2}$ catalysts were also supported on $\mathrm{Al}_{2} \mathrm{O}_{3}$ foams [22]. With respect to the methodology, in most cases the simultaneous reduction of the metal precursors was carried out in $\mathrm{H}_{2} / \mathrm{CO}_{2}$ mixtures. Müller and Türk have successfully deposited AuAg core-shell structures following this methodology [23]. Prof. Erkey and coworkers have also studied the impregnation of both metal precursors on the support followed by thermal decomposition at ambient pressure and proposed the sequential deposition of both metals [14].

In this work, the preparation of PtRu and PtCu bimetallic NPs supported on mesoporous $\mathrm{SiO}_{2}$ SBA-15 (SBA-15) using $\mathrm{scCO}_{2}$ is studied. The utilization of $\mathrm{CO}_{2}$ as solvent and reaction medium in the catalysts preparation may lead to very homogeneous materials. The effect that the reduction methodology has on the chemical composition, structure of the bimetallic material and their catalytic properties is addressed in this paper for the first time.

SBA-15 shows high thermal and chemical stability along a high surface area and an uniform pore size distributions. The support helps to stabilize the nanoparticles, preventing 
their sintering and aggregation and, at the same time, facilitates handling of the catalyst. The addition of $\mathrm{Ru}$ or $\mathrm{Cu}$ to $\mathrm{Pt}$, reduces the cost of the catalyst and may allow a higher selectivity in hydrogenation reactions in comparison to $\mathrm{Pt}$.

As a model reaction to test the materials prepared in $\mathrm{scCO}_{2}$, the hydrogenation of furfural is proposed. Furfural is an important renewable, non-petroleum based, chemical feedstock, which is produced from lignocellulosic residues (agricultural by-products like sugarcane, bagasse and corn cobs). It is considered a potential platform chemical [24] because it can be readily hydrogenated to other value added chemicals such as furfuryl alcohol, 2-methylfuran and the corresponding tetrahydrofuran derivatives, among others.

Different Pd, Pt, Ru, Cu and Pt bimetallic supported based catalysts have been proposed in the hydrogenation of furfural $[25,26]$. Furthermore, the hydrogenation of furfural has been performed in $\mathrm{scCO}_{2}[26,27]$. The tuneable solvent properties and green nature of $\mathrm{scCO}_{2}$ provide a very interesting medium for chemical reactions. Furfural and the possible products are highly soluble in $\mathrm{CO}_{2}$ and $\mathrm{H}_{2} / \mathrm{CO}_{2}$ mixtures at supercritical conditions and the reaction can be performed in the one-phase region. Stevens et al. have shown that by a right combination of catalyst and temperature, a fine control of the product distribution can be achieved [27].

In this work we study the preparation of Pt bimetallic catalysts in $\mathrm{scCO}_{2}$ and its use in the hydrogenation of furfural as a model reaction. The effect that the presence of the two metals and the preparation method has on the catalytic properties of these materials is studied. Both the catalyst preparation and the catalytic reaction are carried out in $\mathrm{scCO}_{2}$, using a renewable feedstock making the whole process sustainable.

\section{MATERIALS AND METHODS}

\subsection{Materials}


The precursors dimethyl(1,5-cyclooctadiene)platinum(II) $\left[\mathrm{Pt}\left(\mathrm{CH}_{3}\right)_{2}(\mathrm{cod})\right](97 \%)$ and bis(2,2,6,6-tetramethyl-3,5-heptanodionato)(1,5-cyclooctadiene) ruthenium(II), $\left[\mathrm{Ru}(\mathrm{tmhd})_{2}(\mathrm{cod})\right] \quad(99 \%)$ and $\operatorname{bis}(2,2,6,6$-tetramethyl-3,5-heptanodionate) copper (II) $\left(\mathrm{Cu}(\mathrm{tmhd})_{2}\right)(99 \%)$ were provided by Strem Chemicals. Tetraethylorthosilicate (TEOS, $>99+\%$ pure), poly(ethylene glycol)-block-poly(propylene glycol)-block-poly(ethylene glycol) $\left(\mathrm{M}_{\mathrm{w}}=5800\right)$ (PEO-PPO-PEO), furfural (99 \%), 1,5-pentanediol (+97\%, GC) and dichloromethane (99.9\%, GC) were purchased from Sigma Aldrich. Furfuryl alcohol (98\%), tetrahydrofurfuryl alcohol (+97\%), 2-methyltetrahydrofurane (+99\%) and 2-methylfuran (99\%) were supplied by Acros Organics. All chemicals were used as received. $\mathrm{CO}_{2}$ (purity $>99.99 \%$ ) and $\mathrm{H}_{2}$ (purity >99.999\%) were supplied by Air Liquide. $\mathrm{H}_{2}(5 \%) / \mathrm{N}_{2}$ was supplied by Contse. Mesoporous silica SBA-15 was synthesized following a procedure similar to that described by Zhao et al.[28, 29] using PEO-PPO-PEO as structure-directing agent and TEOS as precursor. 
The physical properties of the metal precursors are given in Table 1.

Table 1. Physical properties of the metal precursors: molar mass (M), \% metal wt and melting temperature $\left(T_{\mathrm{m}}\right)$

\begin{tabular}{lcccl}
\hline Metal Precursor & $\mathrm{M}(\mathrm{g} / \mathrm{mol})$ & $\%$ metal wt & $T_{\mathrm{m}}\left({ }^{\circ} \mathrm{C}\right)$ & Ref. \\
\hline $\mathrm{Pt}(\mathrm{cod})\left(\mathrm{CH}_{3}\right)_{2}$ & 333.3 & 58.5 & 105 & {$[30]$} \\
$\mathrm{Ru}(\mathrm{tmhd})_{2}(\mathrm{cod})$ & 575.8 & 17.5 & $187-190$ & http://www.strem.com \\
$\mathrm{Cu}(\mathrm{tmhd})_{2}$ & 430.8 & 14.8 & 198 & http://www.strem.com \\
\hline
\end{tabular}

\subsection{Materials preparation}

Catalysts were prepared using a $100 \mathrm{~mL}$ stirred high-pressure Bolted Closure reactor (Autoclave Eng.) or a $60 \mathrm{~mL}$ custom made high-pressure stainless steel reactor heated with a small furnace provided with magnetic stirring. $\mathrm{CO}_{2}$ was introduced into the reactor using a high pressure syringe pump (ISCO 260D), thermostated at 60-80 ${ }^{\circ} \mathrm{C}$, depending on the experiments. When necessary, $\mathrm{H}_{2}$ was introduced into the reactor using a $30 \mathrm{~mL}$ high-pressure auxiliary cell.

The SCFD comprises three different steps: (i) dissolution of the metal precursors in $\mathrm{scCO}_{2}$ at a given conditions, (ii) adsorption of the precursor on the support from the fluid phase and (iii) precursor decomposition to the metal form.

A metal precursor or a mixture of the two metal precursors at the same molar concentration (1:1 molar ratio) and a given amount of support were placed into the reactor. Maximum metal loading for each metal relative to the support was $2 \%$ mol, which represents metal mass percentages of $6.2,3.3$ and $2.1 \%$ wt for $\mathrm{Pt}, \mathrm{Ru}$ and $\mathrm{Cu}$, respectively. The reactor was then 
heated up to the selected temperature and was filled with $\mathrm{CO}_{2}$ from the thermostated syringe pump at a given pressure. The precursor dissolved in $\mathrm{scCO}_{2}$ and adsorbed onto the support. The adsorption equilibrium is governed by the relative affinity among precursors- $\mathrm{CO}_{2}$ (solubility of each precursor), precursor-support (precursor adsorption) and $\mathrm{CO}_{2}$-support $\left(\mathrm{CO}_{2}\right.$ adsorption) and can be tuned with the precursor concentration, pressure and temperature. In this work, the impregnation step for $\mathrm{Pt}$ and $\mathrm{Cu}$ precursors (either separated or mixed) was carried out at $60{ }^{\circ} \mathrm{C}$ and $13.0 \mathrm{MPa}$, whilst for pure and mixed metals containing $\mathrm{Ru}$, impregnation was performed at $80^{\circ} \mathrm{C}$ and $13.5 \mathrm{MPa}$ and $60^{\circ} \mathrm{C}$ and $13.0 \mathrm{MPa}$ (see Table 2). Conditions were selected based on previous results [31, 32]. Impregnation time varied from 1-4 hours.

The concentration of each metal precursor in $\mathrm{CO}_{2}$ was ca. $3.510^{-5}$ in mole fraction. Mole fraction solubility of $\mathrm{Pt}(\mathrm{cod})\left(\mathrm{CH}_{3}\right)_{2}$ and $\mathrm{Cu}(\mathrm{tmhd})_{2}$ in $\mathrm{CO}_{2}$ at $60{ }^{\circ} \mathrm{C}$ and $13.0 \mathrm{MPa}$ were ca. 5.2 $10^{-4}$ and $3.0210^{-4}$, respectively [33], whilst the estimated solubility of $\mathrm{Ru}(\mathrm{tmhd})_{2}(\mathrm{cod})$ in $\mathrm{CO}_{2}$ at $80{ }^{\circ} \mathrm{C}$ and 13.0 MPa was $9.910^{-5}$ [33]. Therefore, precursors were fully soluble at the impregnation conditions.

The metal precursors adsorbed on the support were reduced to the metal form following: chemical reduction with $\mathrm{H}_{2}$ in the supercritical mixture (reactive deposition, $\mathrm{RD}$ ) or chemical reduction in $\mathrm{H}_{2}(5 \%) / \mathrm{N}_{2}$ flow at low pressure in a tubular furnace (impregnation/reduction, IR). Scheme 1 summarizes the methods used. 


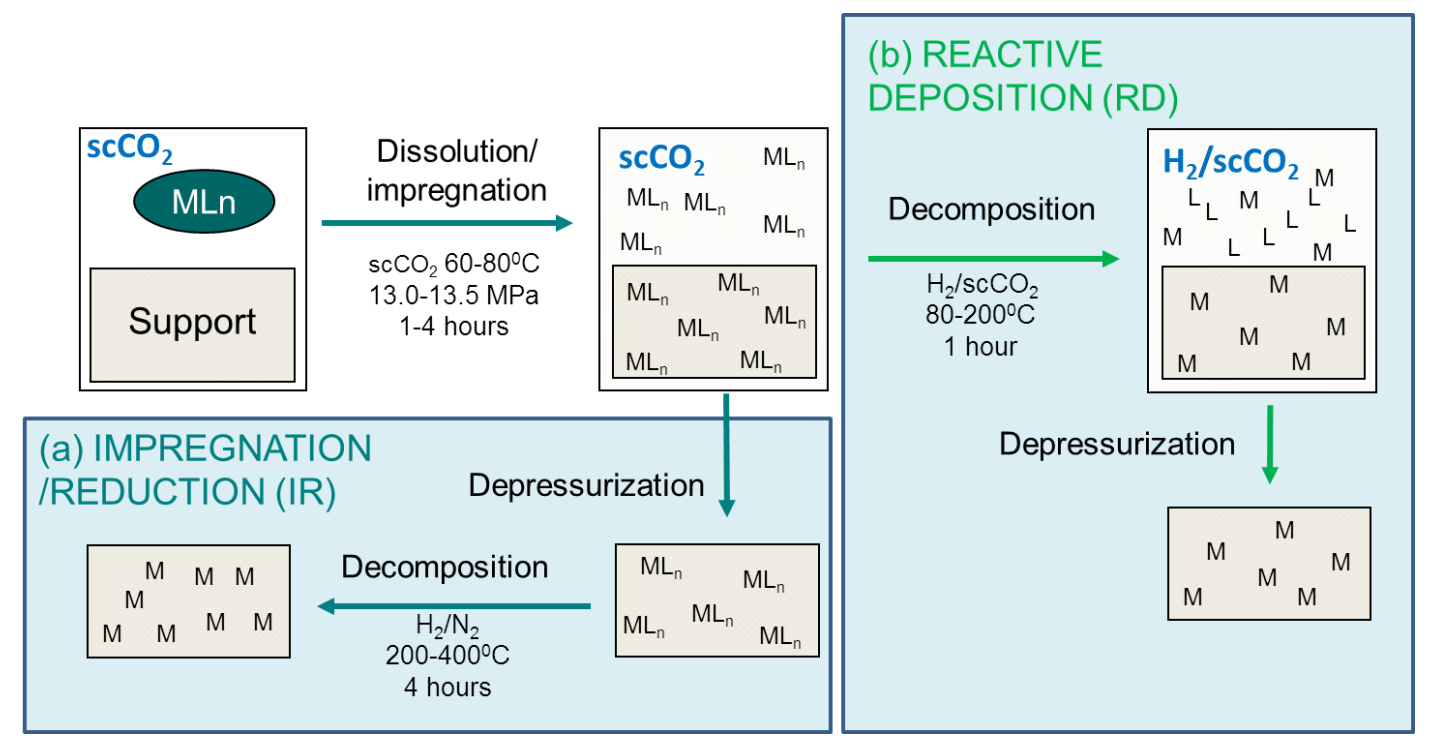

Scheme 1. Methodologies employed in the Supercritical Fluid Deposition (SCFD) of metal nanoparticles. The first step involving the precursor dissolution in $\mathrm{scCO}_{2}$ and the impregnation of the support is common to both and it is followed by: (a) despressurization and reduction in $\mathrm{H}_{2} / \mathrm{N}_{2}$ (impregnation/reduction, IR) or (b) reactive deposition in $\mathrm{H}_{2} / \mathrm{scCO}_{2}$ at high temperature (reactive deposition, RD).

In the reactive deposition, $\mathrm{H}_{2}$ was introduced into the reactor containing the supercritical mixture and the temperature was risen. Precursor reduction was carried out in $\mathrm{H}_{2} / \mathrm{scCO}_{2}$ at $80^{\circ} \mathrm{C}$ and 18.0 MPa (Pt) or $150-200^{\circ} \mathrm{C}$ and ca. $30.0 \mathrm{MPa}(\mathrm{Ru}, \mathrm{Cu}$ and the Pt bimetallics) for 1 hour. In the impregnation/reduction, reduction was performed after depressurization at atmospheric pressure in $\mathrm{H}_{2} / \mathrm{N}_{2}$ atmosphere and a tubular furnace at $200^{\circ} \mathrm{C}(\mathrm{Pt})$ or $400^{\circ} \mathrm{C}(\mathrm{Ru}$, $\mathrm{Cu}$ and the Pt bimetallics) for 4 hours. 


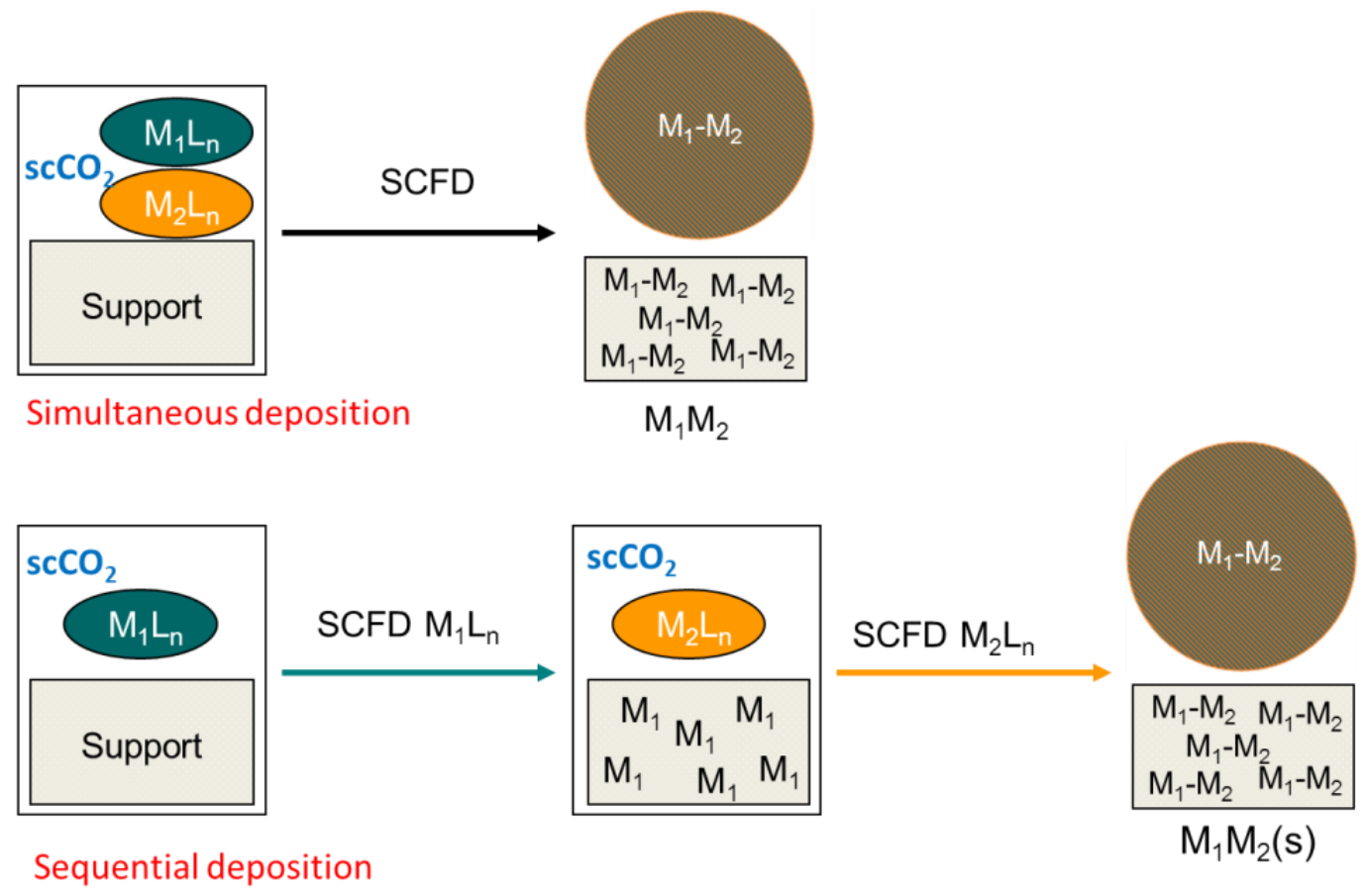

Scheme 2- Simultaneous and sequential deposition of bimetallic compounds by the Supercritical Fluid Deposition (SCFD). Each step can be performed by impregnation/reduction or reactive deposition following Figure 1.

Both, the simultaneous impregnation of the two metals and the sequential deposition of each metal were attempted, following the methodologies described previously (Scheme 2). The simultaneous deposition involves the addition of both metal precursors simultaneously to the reactor. On the other hand, the sequential methodology (s) consists on depositing the first metal $\left(M_{1}\right)$ as a seed and, on a second step, depositing the second metal $\left(M_{2}\right)$ leading to $M_{1} M_{2}$. The order of deposition of each metal was varied. These materials are referred as $\mathrm{PtRu}(\mathrm{s})$, $\mathrm{RuPt}(\mathrm{s}), \mathrm{PtCu}(\mathrm{s})$ and $\mathrm{CuPt}(\mathrm{s})$. Furthermore the reduction was performed following reactive deposition or impregnation on each step as previously described, giving rise to many different combinations. Pressure and temperature conditions used in each methodology for each metal or bimetallic mixture are summarized in Table 2 . 
Table 2. Summary of the experimental conditions ( $\mathrm{T}$ and $\mathrm{P}$ ) used in the SCFD of Pt, Ru and $\mathrm{Cu}$ and the bimetallic $\mathrm{PtRu}$ and $\mathrm{PtCu}$ prepared by simultaneous deposition following the different methodologies: impregnation/reduction (IR) and reactive deposition (RD). For the bimetallic materials prepared by sequential deposition, the conditions are those used for the pure metal deposition in each step.

\begin{tabular}{cccccc}
\hline \multirow{2}{*}{ Metals } & \multirow{2}{*}{ Methodology } & \multicolumn{2}{c}{ Impregnation } & \multicolumn{2}{c}{ Reduction } \\
& & $\mathrm{T}\left({ }^{\circ} \mathrm{C}\right)$ & $\mathrm{P}(\mathrm{MPa})$ & medium & $\mathrm{T}\left({ }^{\circ} \mathrm{C}\right)$ \\
\hline $\mathrm{Pt}$ & $\mathrm{IR}$ & 60 & 13.0 & $\mathrm{H}_{2} / \mathrm{N}_{2}{ }^{\mathrm{a}}$ & 200 \\
$\mathrm{Pt}$ & $\mathrm{RD}$ & 60 & 13.0 & $\mathrm{H}_{2} / \mathrm{CO}_{2}$ & 80 \\
$\mathrm{Ru}$ & $\mathrm{IR}$ & 80 & 13.5 & $\mathrm{H}_{2} / \mathrm{N}_{2}{ }^{\mathrm{a}}$ & 400 \\
$\mathrm{Ru}$ & $\mathrm{RD}$ & 80 & 13.5 & $\mathrm{H}_{2} / \mathrm{CO}_{2}$ & 150 \\
$\mathrm{Cu}$ & $\mathrm{IR}$ & 60 & 13.0 & $\mathrm{H}_{2} / \mathrm{N}_{2}{ }^{\mathrm{a}}$ & 400 \\
$\mathrm{PtRu}$ & $\mathrm{IR}$ & 80 & 13.5 & $\mathrm{H}_{2} / \mathrm{N}_{2}{ }^{\mathrm{a}}$ & 400 \\
$\mathrm{PtRu}$ & $\mathrm{RD}$ & 60 & 13.0 & $\mathrm{H}_{2} / \mathrm{CO}_{2}$ & 200 \\
$\mathrm{PtCu}$ & $\mathrm{IR}$ & 60 & 13.5 & $\mathrm{H}_{2} / \mathrm{N}_{2}{ }^{\mathrm{a}}$ & 400 \\
$\mathrm{PtCu}$ & $\mathrm{RD}$ & 60 & 13.5 & $\mathrm{H}_{2} / \mathrm{CO}_{2}$ & 200 \\
\hline
\end{tabular}

a Atmospheric pressure

\subsection{Materials characterization.}

Transmission Electron Microscopy (TEM), Energy-Dispersive X-ray analysis (EDX) and X-Ray Diffraction (XRD) were used to characterize the samples. TEM were performed using a JEOL JEM 2100 electron microscope working at $200 \mathrm{kV}$ and a JEOL-JEM 3000F electron microscope operating at $300 \mathrm{kV}$. Both TEM microscopes were equipped with a double tilting Be sample holder $\left( \pm 25^{\circ}\right)$ and EDX (Oxford INCA). Samples were dispersed in 1-butanol over copper or nickel grids (for those samples containing $\mathrm{Cu}$ ) and dried in air. Particle size 
distribution was obtained from the TEM images. Metal loading of all the samples was measured by EDX. The JEOL 3000F microscope was used in the Scanning Transmission Electron Microscopy (STEM) mode, using the EDX analysis to determine the architecture of the bimetallic NPs. For the RuPt and the CuPt samples, samples were carbon coated before analysis in an effort to improve stability under the electron beam. Wide angle XRD patterns of the composite materials were collected using a X'PERT MPD diffractometer with $\mathrm{Cu} \mathrm{K \alpha}$ radiation at $2 \theta$ values between 10 and $90^{\circ}$. The Scherrer equation was employed to estimate the crystallite size.

\subsection{Catalytic tests}

Catalytic test were performed in the batch mode. A given amount of the furfural and the catalyst with a molar ratio substrate to metal equal to 200:1 and a stirring bar were placed in a $60 \mathrm{~mL}$ high-pressure stainless-steel reactor. The reactor was provided with a custom made heating aluminum jacket. No prior activation of the catalysts was performed. The system was sealed and purged with $\mathrm{CO}_{2}$ at low pressure several times. Then the reactor was heated at 80 ${ }^{\circ} \mathrm{C}$ and $\mathrm{CO}_{2}$ was added to the reactor from a thermostated ISCO syringe pump at the same temperature up to a total pressure of 10.0 MPa. Afterwards 4-6 $\mathrm{MPa} \mathrm{H}_{2}$ depending on the experiment, were added from a $30 \mathrm{~mL}$ high-pressure auxiliary cell to the reactor by flowing $\mathrm{CO}_{2}$ through the cell to the reactor up to a final pressure of $18.0 \mathrm{MPa}$. Contents of the cell were stirred with a magnetic stirrer. The $\mathrm{H}_{2}$ to furfural molar ratio was $25: 1$. Reaction time was measured after the $\mathrm{H}_{2} / \mathrm{CO}_{2}$ addition once the reaction conditions were reached. Samples were taken using a high-pressure 6-way valve (Valco) with a $500 \mu \mathrm{L}$ loop at regular times from 30 to $180 \mathrm{~min}$. The reaction was terminated by placing the reactor into a water/ice bath, 
followed by depressurization over a small amount of dichloromethane and further washing the reactor with more dichloromethane. The solid catalyst was separated from the reaction mixture by filtration.

The products were analyzed using a Shimadzu 2010 Plus gas chromatograph equipped with a Flame Ionization Detector (FID) and a Zebron ZB-1HT capillary column (20 m x $0.18 \mathrm{~mm}$ i.d. $\mathrm{x} 0.18 \mu \mathrm{m}$ film thickness). $\mathrm{N}_{2}$ was used as carrier gas and flowed at $30 \mathrm{~mL} / \mathrm{min}$. The column temperature was initially held at $60{ }^{\circ} \mathrm{C}$ for $4 \mathrm{~min}$, then ramped at $20{ }^{\circ} \mathrm{C} \mathrm{min}$ m $^{-1}$ to 200 ${ }^{\circ} \mathrm{C}$ and then held at this temperature for 3 min. Injector and detector temperature was $250{ }^{\circ} \mathrm{C}$ with a split ratio of 300 . Peak assignments were confirmed with standard samples of commercially available compounds. Quantification was performed by integrated peak area normalization.

\section{RESULTS AND DISCUSSION}

\subsection{Metal Deposition}

Deposition of PtRu and PtCu NPs into mesoporous silica SBA-15 was carried out following both reduction methodologies: impregnation/reduction and reactive deposition (Scheme 1) and the simultaneous and sequential deposition (Scheme 2). The precursor molar ratio was

1:1. For comparison purposes $\mathrm{Pt}, \mathrm{Ru}$ and $\mathrm{Cu}$ NPs were also successfully deposited on SBA15. 
XRD patterns of the PtRu and $\mathrm{PtCu}$ bimetallic materials prepared are shown in Figures 1 and 2, respectively. Figure 1 also shows the XRD pattern of pure Pt. The wide signal centered at $2 \theta \sim 22^{\circ}$ is ascribed to the mesoporous $\mathrm{SiO}_{2}$ support. Further peaks at $39.8^{\circ}, 46.2^{\circ}, 67.5^{\circ}$ and $81.3^{\circ}$ fit to the (111), (200), (220) and (311) reflections of cubic Pt (PDF 040802). Due to the low metal concentration and small particle size, XRD patterns for pure $\mathrm{Ru}$ and $\mathrm{Cu}$ did not show clear reflection.

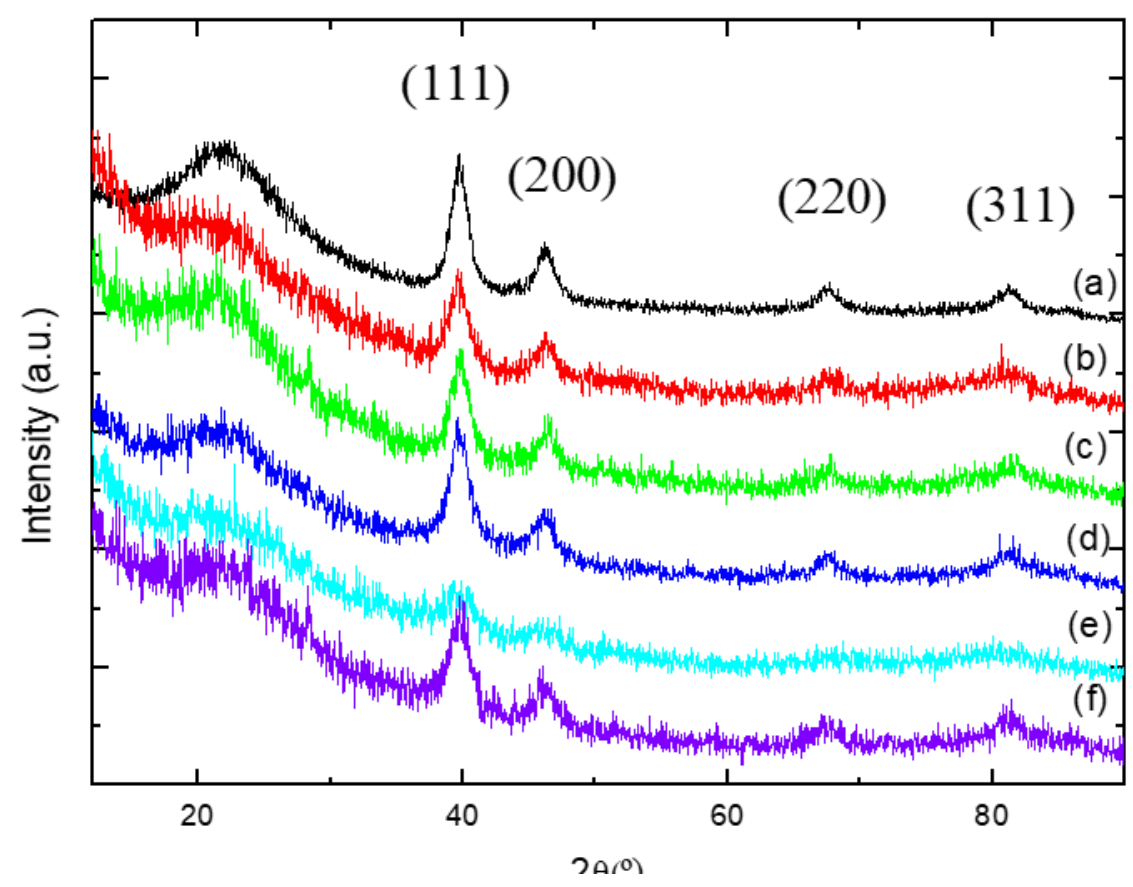

Figure 1. XRD patterns of the PtRu bimetallic samples on SBA-15 prepared by SCFD: (a) PtRu RD, (b) PtRu IR, (c) PtRu(s) RD-RD, (d) RuPt(s) IR-RD, (e)RuPt(s) IR-IR and (f) Pt IR 


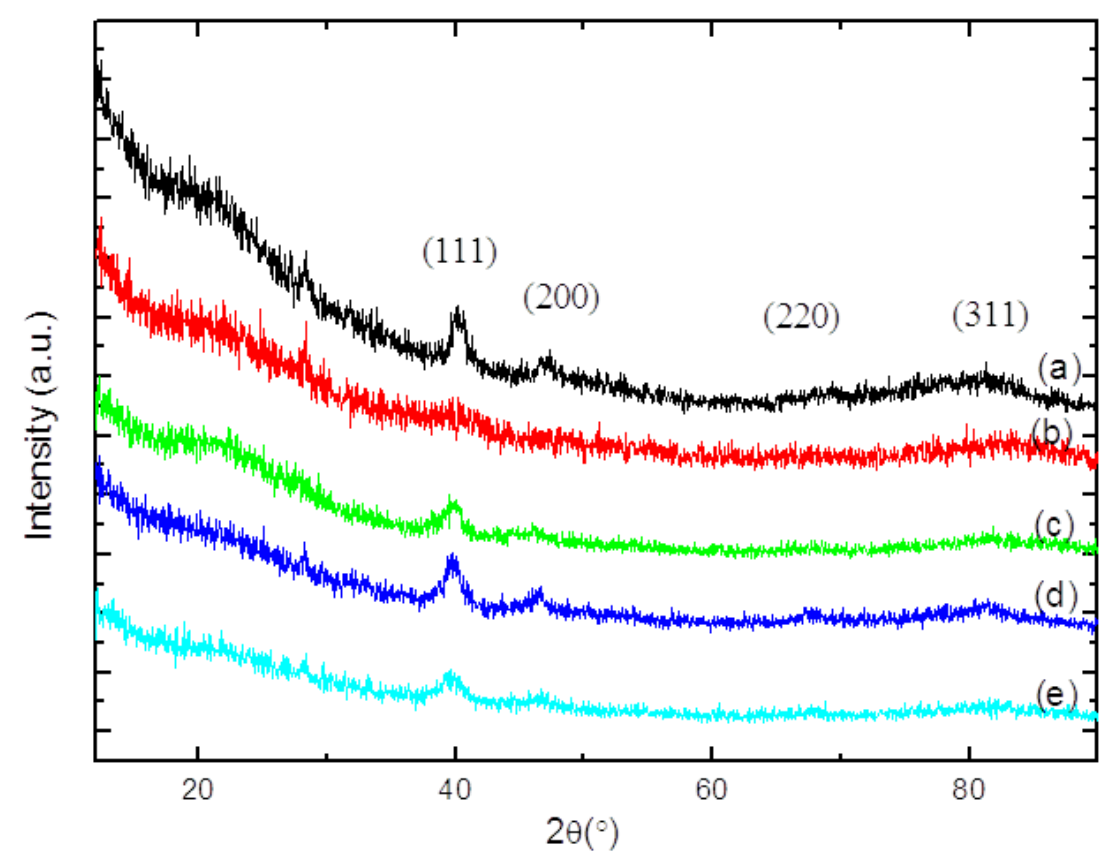

Figure 2. XRD patterns of the PtCu bimetallic samples on SBA-15 prepared by SCFD: (a) $\mathrm{PtCu}$ RD, (b) PtCu IR, (c) PtCu(s) RD-RD, (d) CuPt(s) IR-RD and (e) CuPt(s) IR-IR.

For compositions less than $60 \% \mathrm{~mol} \mathrm{Ru}$, the PtRu bulk phase diagram[34] show the formation of substitutional solid solutions (disordered structures or alloys) in which the $\mathrm{Pt}$ cubic structure is maintained and some Pt atoms are replaced by the smaller Ru atoms. Therefore, typical Pt alloys show a slight shift of the diffraction peaks maxima $[18-20,35$, 36]. Similarly, PtCu bulk phase diagram[37] show, at high T, the formation of continuous cubic solid solutions. At lower temperatures, however, several ordered structures or intermetallic compounds are reported. On the other hand, the stabilization of different structures from the bulk in bimetallic NPs has been also reported.[38] For both PtRu and $\mathrm{PtCu}$ NPs deposited in $\mathrm{scCO}_{2}$, XRD patterns suggest the formation of a cubic alloy type of structure. However, it is difficult to assert the shift of the diffraction peaks at higher $2 \theta$ values from the original Pt structure, particularly for the samples deposited by sequential deposition. This 
could be due in part to the small $\mathrm{Ru}$ and $\mathrm{Cu}$ content in the samples in comparison to $\mathrm{Pt}$, related to their lower metal molecular mass.

Selected $\mathrm{PtCu}$ and CuPt samples were annealed at 600 and $900^{\circ} \mathrm{C}$ in $\mathrm{H}_{2} / \mathrm{N}_{2}$ in a tubular furnace for 3 hours. Peak position of the (111) reflection for cubic Pt shifted slightly to larger $2 \theta$ values after annealing particularly in the samples deposited by sequential deposition. The largest shift was observed for the $\mathrm{CuPt}(\mathrm{s}) \mathrm{IR}-\mathrm{RD}$ sample in which $\mathrm{Pt}$ was deposited on a $\mathrm{Cu}$ seed at $80^{\circ} \mathrm{C}$. The low temperature employed in the Pt deposition may have produced a coreshell structure. Alloying of the metals was promoted with annealing. (See Supplementary Material).

Particle size of the different samples as-prepared estimated from the fit of the (111) Pt peak to the Scherrer equation are also given in Table 3. XRD peaks for the $\mathrm{PtCu}$ sample prepared by IR were too weak to perform this estimation.

Transmission Electron Microscopy (TEM) images of the different samples are shown in Figures 3 to 5. TEM images showed the cylindrical pores of the SBA-15 support along with the metal NPs. The size of the support pores is between 6-7 nm, which agrees well with the pore size determined from $\mathrm{N}_{2}$-adsorption $(6.4 \mathrm{~nm})$ [39]. Average particle sizes obtained from the TEM images are reported in Table 3.

The ordered structure of the porous support was confirmed by small angel XRD. Deposition of $\mathrm{Pd}$ on $\mathrm{SiO}_{2} \mathrm{SBA}-15$ using $\mathrm{scCO}_{2}$ showed that the porous structure and ordering of the support were preserved after the deposition process, with no change on the cell parameters [40]. 
Table 3. Summary of the metal deposition experiments by SCFD, showing the methodology: impregnation/reduction (IR) and reactive deposition (RD) for 1:1 initial metal molar ratios. For the sequential deposition (s), depending on the order of deposition, samples are named $\operatorname{PtRu}(\mathrm{s})$ or $\mathrm{RuPt}(\mathrm{s})$ and $\mathrm{PtCu}(\mathrm{s})$ or $\mathrm{CuPt}(\mathrm{s}) . \mathrm{M}_{1}$ and $\mathrm{M}_{2}$ molar metal loads on SBA-15 and $\mathrm{M}_{1}: \mathrm{M}_{2}$ metal molar ratio were measured by EDX. Average crystallite size was estimated from the XRD patterns applying the Sherrer equation to the Pt (111) peak. Particle size averages were determined from the particle size distribution measured from TEM.

\begin{tabular}{|c|c|c|c|c|c|c|}
\hline \multirow{2}{*}{$\begin{array}{l}\text { Sample } \\
\mathrm{M}_{1} \mathrm{M}_{2}\end{array}$} & \multirow[t]{2}{*}{ Method } & \multirow{2}{*}{$\begin{array}{c}\text { Molar } \\
\text { Ratio } \\
\mathrm{M}_{1}: \mathrm{M}_{2}\end{array}$} & \multicolumn{2}{|c|}{$\begin{array}{c}\text { Metal on } \mathrm{SiO}_{2} \\
(\% \mathrm{~mol})\end{array}$} & \multirow{2}{*}{$\begin{array}{l}\text { Scherrer } \\
\text { Crystallite } \\
\text { size }(\mathrm{nm})\end{array}$} & \multirow{2}{*}{$\begin{array}{c}\text { TEM } \\
\text { Particle size } \\
(\mathrm{nm})\end{array}$} \\
\hline & & & $\mathrm{M}_{1}$ & $\mathrm{M}_{2}$ & & \\
\hline $\mathrm{PtRu}$ & IR & $60: 40$ & 1.6 & 1.2 & 4.7 & $4.6 \pm 0.5$ \\
\hline $\mathrm{PtRu}$ & $\mathrm{RD}$ & $70: 30$ & 1.2 & 0.49 & 5.8 & $5.7 \pm 0.6$ \\
\hline $\operatorname{PtRu}(\mathrm{s})$ & RD-RD & $60: 40$ & 1.6 & 1.2 & 5.5 & $8.7 \pm 1.2 *$ \\
\hline $\operatorname{RuPt}(\mathrm{s})$ & IR-IR & $55: 45$ & 1.8 & 1.4 & 3.2 & $3.5 \pm 0.6$ \\
\hline $\operatorname{RuPt}(\mathrm{s})$ & IR-RD & $50: 50$ & 1.8 & 1.8 & 5.1 & $4.6 \pm 0.5$ \\
\hline $\mathrm{PtCu}$ & IR & $70: 30$ & 1.6 & 0.73 & - & $4.8 \pm 0.6$ \\
\hline $\mathrm{PtCu}$ & $\mathrm{RD}$ & $85: 15$ & 1.6 & 0.33 & 8.4 & $10.7 \pm 0.7 *$ \\
\hline $\mathrm{PtCu}(\mathrm{s})$ & RD-RD & $70: 30$ & 1.6 & 0.61 & 5.0 & $5.0 \pm 0.4$ \\
\hline $\mathrm{CuPt}(\mathrm{s})$ & IR-IR & $45: 55$ & 1.6 & 1.9 & 4.5 & $4.6 \pm 0.5$ \\
\hline $\operatorname{CuPt}(\mathrm{s})$ & IR-RD & $50: 50$ & 1.6 & 1.6 & 5.6 & $4.1 \pm 0.5$ \\
\hline
\end{tabular}

*Rod-like particles. The size indicates the rod length and the diameter is ca. $7 \mathrm{~nm}$. 

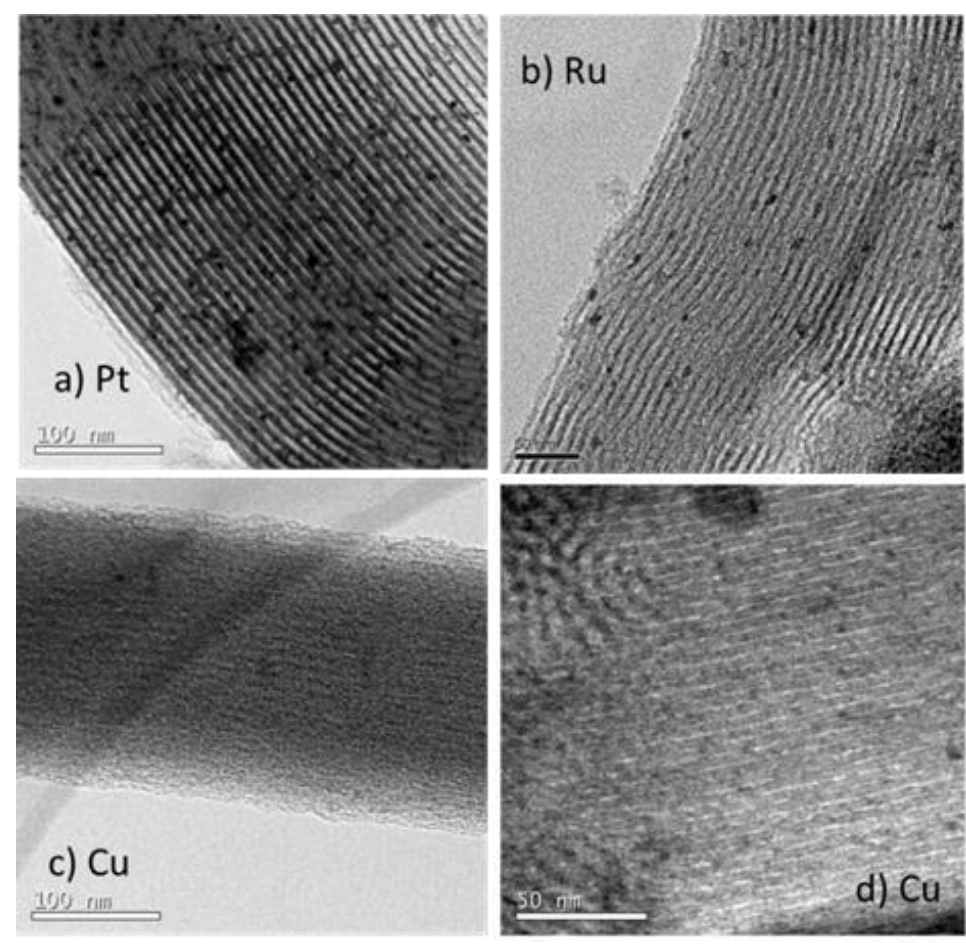

Figure 3. TEM images of metal samples on SBA-15 prepared by SCFD and impregnation/reduction: (a) Pt, (b) $\mathrm{Ru}$ (c) $\mathrm{Cu}$.

TEM images of the $\mathrm{Pt}, \mathrm{Ru}$ and $\mathrm{Cu}$ NPs obtained by the impregnation/reduction methodology are shown in Figure 3. Previous results showed that smaller particles were obtained when this methodology is used [26, 27]. Pt and Ru NP of 3-4 nm size were clearly located inside the SBA-15 mesopores. Particles were homogeneously distributed throughout the support pores. $\mathrm{Cu}$ NPs deposited on SBA-15 were much smaller and almost imperceptible by TEM (Figures 3c-d). Pt, Ru and $\mathrm{Cu}$ metal loads on SBA-15 determined by EDX on the TEM images varied from 1.6 to $2.0 \%$ mol. At the impregnation conditions (see Table 2 in experimental section), $\mathrm{Ru}$ and $\mathrm{Cu}$ precursors seem to adsorb less strongly to the silica support than the Pt precursor leading to slightly lower loads. 

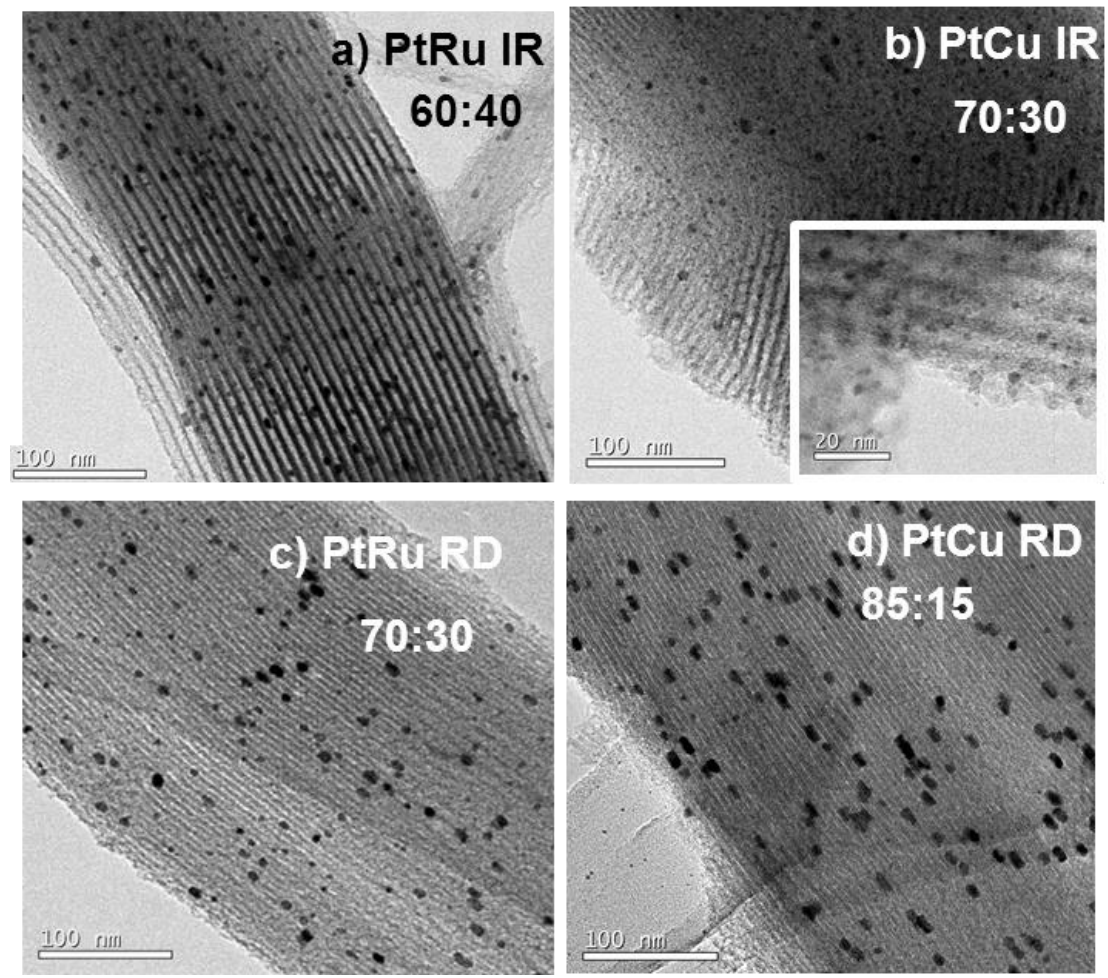

Figure 4. TEM images and $\mathrm{Pt}$ to $\mathrm{Ru}$ or $\mathrm{Pt}$ to $\mathrm{Cu}$ molar ratios for the bimetallic samples on SBA-15 prepared by SCFD simultaneous deposition: (a) PtRu IR, (b) PtCu IR (c) PtRu RD and (d) PtCu RD.

TEM images of the different bimetallic samples are shown in Figures 4 and 5. Samples prepared by impregnation/reduction showed small metal particles mostly spherical confined into the $\mathrm{SiO}_{2}$ mesopores, which do no aggregate. When the reactive deposition was used, particle size distribution broadened and elongate particles were obtained.

Spherical PtRu particles were deposited by impregnation/reduction with an average size of $4.7 \mathrm{~nm}$ (Figure 4a). The PtRu material obtained by reactive deposition however showed larger particles of $5.7 \mathrm{~nm}$ average and a broader particle size distribution (4-8 nm) (Figure 4c).

Similarly, PtCu NPs deposited by reactive deposition were much larger than those deposited by impregnation/reduction. The $\mathrm{PtCu}$ sample obtained by impregnation/reduction 
(Figure 4b) exhibited a bimodal particle size distribution with very small particles between 1$2 \mathrm{~nm}$ and larger elongated particles of ca. $4.8 \mathrm{~nm}$. This may suggest at least partial segregation of the metals on the support [31]. In comparison, the PtCu NPs prepared by reactive deposition became rods of $7 \mathrm{~nm}$ diameter and lengths up to $18 \mathrm{~nm}$ (figure 4d), with an average size of $10.7 \mathrm{~nm}$. Estimates obtained applying the Scherrer equation showed the same trend, with values always smaller for the samples prepared by impregnation/reduction. As expected, for the $\mathrm{PtCu} \mathrm{RD}$ rod-like particles, differences between the particle size and the crystallite size from XRD were larger.

Although the temperature used in the reactive deposition experiments of the bimetallic materials $\left(200^{\circ} \mathrm{C}\right)$ was generally lower than the temperatures employed in the reduction step of the impregnation/reduction methodology $\left(200-400^{\circ} \mathrm{C}\right)$, particles obtained by reactive deposition grew larger. In the impregnation/reduction methodology, the organometallic compounds are reduced and the ligands decomposed to be removed from the surface, whilst in the reactive deposition, the precursors are only hydrogenated and the ligands solubilized in $\mathrm{scCO}_{2}$. Therefore reduction temperatures are generally lower in $\mathrm{H}_{2} / \mathrm{scCO}_{2}$. However, when the simultaneous reactive deposition was performed, Pt was probably reduced first and could catalyze afterwards the reduction of $\mathrm{Ru}$ or $\mathrm{Cu}$.

Bimetallic NPs were always much larger than the monometallic ones. This is partially due to the larger total metal loads and to the higher temperatures used in the reduction step of the bimetallic samples in comparison to those of pure Pt (see Table 2).

Average metal loadings estimated from Energy-Dispersive X-ray (EDX) analysis are given in Table 3 and Figures 4 and 5. Pt to Ru metal molar ratios equal to 70:30 and 60:40 were obtained by reactive deposition and simultaneous impregnation/reduction, respectively. 
Simultaneous deposition of $\mathrm{PtCu}$ was however more complex and led to $\mathrm{Cu}$ loads much lower than the expected one, and $\mathrm{Pt}$ to $\mathrm{Cu}$ molar ratios of $85: 15$ and 70:30 obtained by simultaneous reactive deposition and impregnation/reduction, respectively. The larger incorporation of $\mathrm{Pt}$ in all the samples is due to the stronger interaction of the Pt precursor with the SBA-15 support in comparison to that of the $\mathrm{Ru}$ and $\mathrm{Cu}$ precursors. Higher metal loadings and metal molar ratios closer to the initial ones were obtained by impregnation/reduction, which suggest the partial reduction of both precursors in the supercritical phase in the reactive deposition.

TEM images of the bimetallic NPs deposited on SBA-15 by sequential deposition are shown in Figure 5. Preparation of $\mathrm{PtRu}(\mathrm{s})$ and $\mathrm{PtCu}(\mathrm{s})$ was performed sequentially depositing Pt in the first place, followed by reactive deposition of $\mathrm{Ru}$ or $\mathrm{Cu}$. We chose this methodology because of the lower temperature and shorter time employed, with the aim to promote coreshell structures. PtRu(s) particles grew larger and became slightly elongated (Figure 5a), with an average length of $8.7 \mathrm{~nm}$. In the $\mathrm{PtCu}(\mathrm{s})$ sample (Figure 5b), however, particles were much smaller than those obtained in the PtRu(s) sample (5.0 nm). EDX analysis of the PtRu(s) and $\mathrm{PtCu}(\mathrm{s})$ samples did not lead to the 1:1 molar metal ratio; $60: 40$ and 70:30 molar ratios were obtained, respectively. Considering than the Pt seed used in both experiments is the same, the lower incorporation of $\mathrm{Cu}$ in $\mathrm{PtCu}(\mathrm{s})$ may partly explain the lower particle size. 

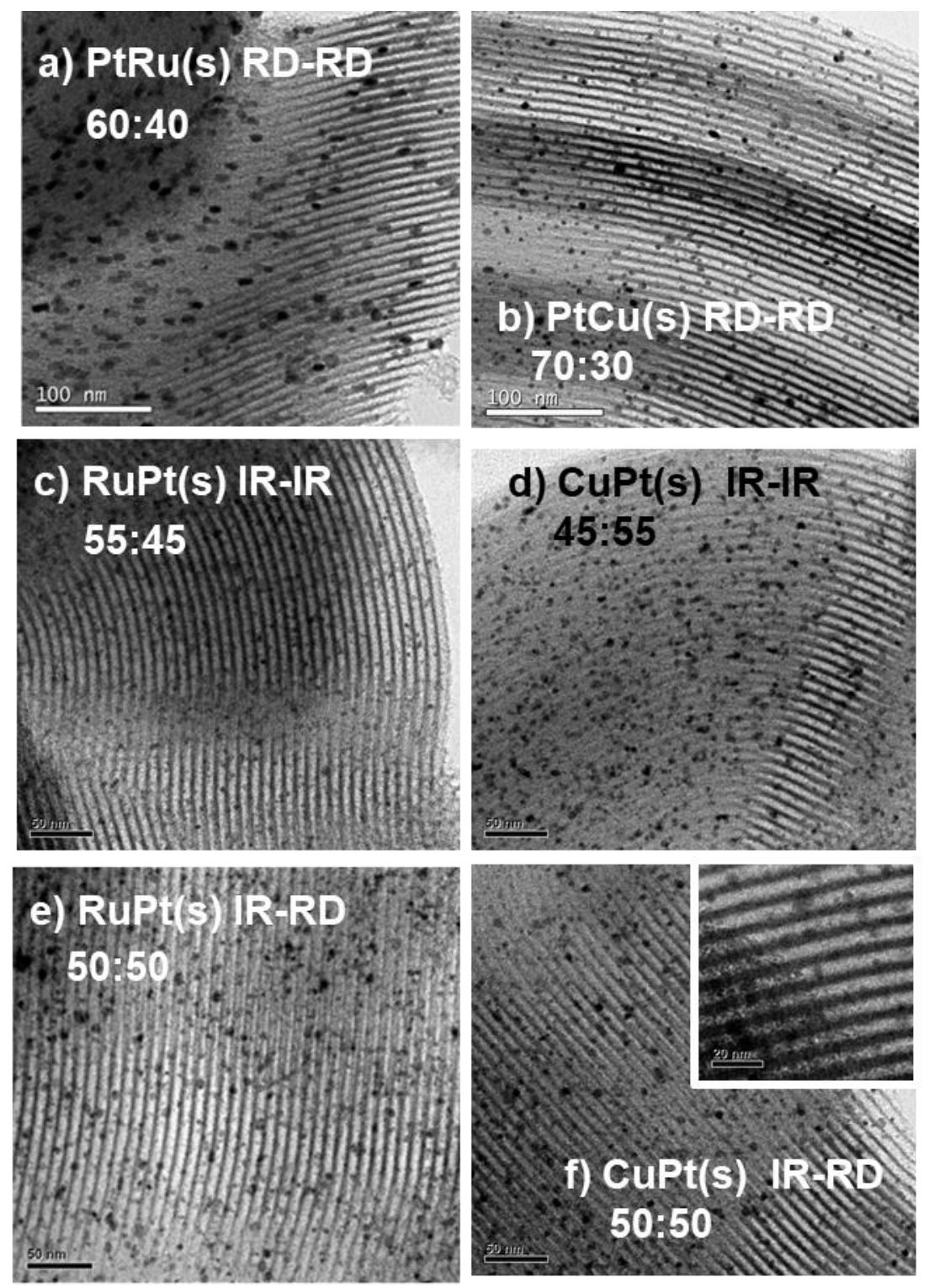

Figure 5. TEM images and molar ratios $\left(\mathrm{M}_{1}\right.$ to $\left.\mathrm{M}_{2}\right)$ of bimetallic samples $\left(\mathrm{M}_{1} \mathrm{M}_{2}\right)$ on SBA-15 prepared by SCFD sequential deposition: (a) PtRu(s) RD-RD, (b) PtCu(s) RD-RD, (c) RuPt(s) IR-IR, (d) CuPt(s) IR-IR (e) RuPt(s) IR-RD and (f) CuPt(s) IR-RD.

Then the order in the metal deposition was changed and $\operatorname{RuPt}(\mathrm{s})$ and $\mathrm{CuPt}(\mathrm{s})$ samples were prepared. In the $\operatorname{RuPt}(\mathrm{s})$ and $\mathrm{CuPt}(\mathrm{s})$ samples, deposition of the first metal $(\mathrm{Ru}$ or $\mathrm{Cu})$ was always performed by impregnation/reduction in order to get the smallest particles. Then Pt 
was deposited onto the $\mathrm{Ru}$ or $\mathrm{Cu}$ NPs through either impregnation/reduction or reductive deposition. In both cases, TEM images showed a large number of spherical NPs homogeneously distributed into the SBA-15 mesopores. Particles did not aggregate. No much differences in the particle sizes were found between the $\operatorname{RuPt}(\mathrm{s})$ and $\mathrm{CuPt}(\mathrm{s})$ samples prepared sequentially and the different methodologies used to deposit the second metal. Average sizes ranging from 3.5 to $4.6 \mathrm{~nm}$ were obtained (Figures 5c-f). Interestingly, whilst for $\operatorname{RuPt}(\mathrm{s})$ particles grew larger when $\mathrm{Pt}$ was deposited by $\mathrm{RD}$ (Figure 5e), for $\mathrm{CuPt}(\mathrm{s})$, average particle size was slightly smaller in this case (Figure 5f). For this sample, a higher magnification TEM image shows the presence of very small particles, which broaden the particle size distribution and shift the average size to lower values.

In both cases, EDX analysis showed molar metal ratios very close to the 1:1 ratio. By depositing $\mathrm{Cu}$ or $\mathrm{Ru}$ in the first place, the incorporation of these metals to the system is favored and the final metal ratio in the NPs is closer to the equimolar ratio.

For the sequential deposition experiments, samples were studied by STEM. STEM-EDX images in $\mathrm{Z}$ contrast are shown in Figure 6 for $\mathrm{PtRu}(\mathrm{s}) \mathrm{RD}-\mathrm{RD}$ ( $\mathrm{Ru}$ over a $\mathrm{Pt}$ seed). Composition analysis for this sample did not show a core-shell structure and overlapping of the $\mathrm{Pt}$ and $\mathrm{Ru}$ signals along each particle were observed, which suggested an alloy type structure. Ru precursor was reduced on the $\mathrm{Pt}$ seed at $200^{\circ} \mathrm{C}$ for 1 hour. 

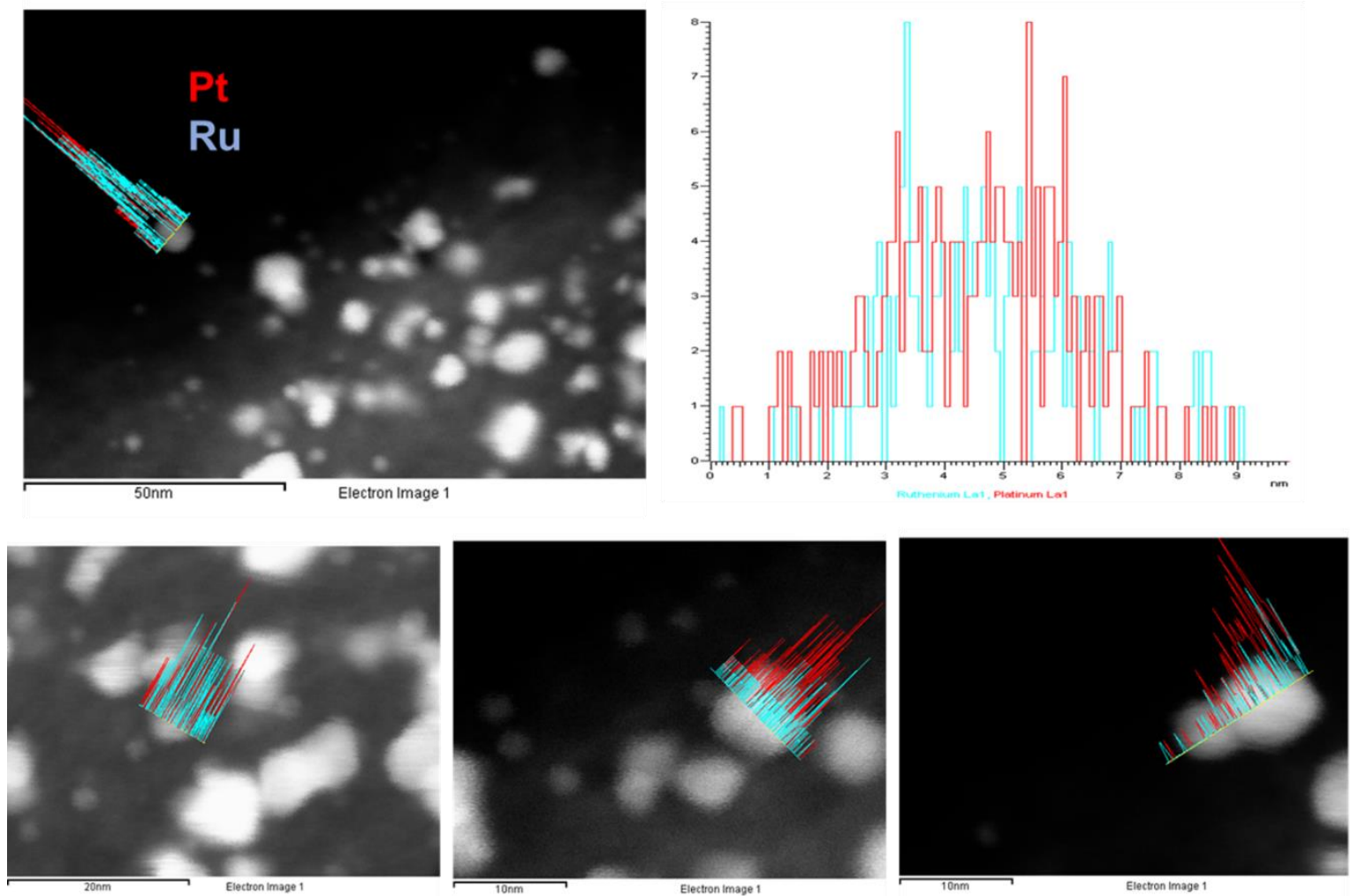

Figure 6. STEM image of PtRu(s) RD-RD on SBA-15 in Z contrast. Composition profiles (right) along single NPs are presented, showing the relative abundance of Pt in red and Ru in blue (arbitrary units).

Analysis of the RuPt(s) and $\mathrm{CuPt}(\mathrm{s})$ samples deposited on SBA-15 by the same technique was unsuccessful due to the smaller particle size and the instability of the samples to the electron beam that drifted the sample during the EDX analysis. Considering that in the sequential deposition, $\mathrm{Pt}$ was deposited at very low temperature by reactive deposition $\left(80^{\circ} \mathrm{C}\right)$, the possibility of a core-shell structure cannot be ruled out.

In conclusion, the SCFD technique is a very versatile technique that allows the deposition of $\mathrm{PtRu}$ and $\mathrm{PtCu}$ bimetallic NPs homogeneously on mesoporous $\mathrm{SiO}_{2} \mathrm{SBA}-15$. In comparison to previous reports on the preparation of Pt bimetallic supported NPs using $\mathrm{scCO}_{2}$, 
particles are slightly larger than those previously deposited on carbon based supports[14] and of similar size to the PtPd NPs on SBA-15 [17].

\subsection{CATALYTIC TESTS}

The catalytic activity of selected samples synthesized using $\mathrm{scCO}_{2}$ was studied for the hydrogenation of furfural at $80^{\circ} \mathrm{C}$ following the procedure described in the experimental section. In particular, only the samples prepared by sequential deposition with metal ratios close to the stoichiometric were tried. Composition of the reaction mixture was analyzed for 30 to 120 or 180 minutes at regular intervals.

Much higher temperatures $[26,27,41]$ and longer times $[26,42]$ than those employed in this work have been previously used for the same reaction in $\mathrm{scCO}_{2}$ and other conventional biphasic hydrogenation processes. Therefore, the conditions chosen in this work are more sustainable.

Scheme 3 shows the proposed pathway reaction for the hydrogenation of furfural (FF) under the present conditions. Major hydrogenation products were furfuryl alcohol (FFA) and tetrahydrofurfuryl alcohol (THFA). 2-Methylfuran (2-MF), 2-methyltetrahydrofuran (2MTHF) and 1,5-pentanediol (1,5-PD) were also identified although in a very small concentration. Other minor products not identified were considered in the calculations as unknowns. 


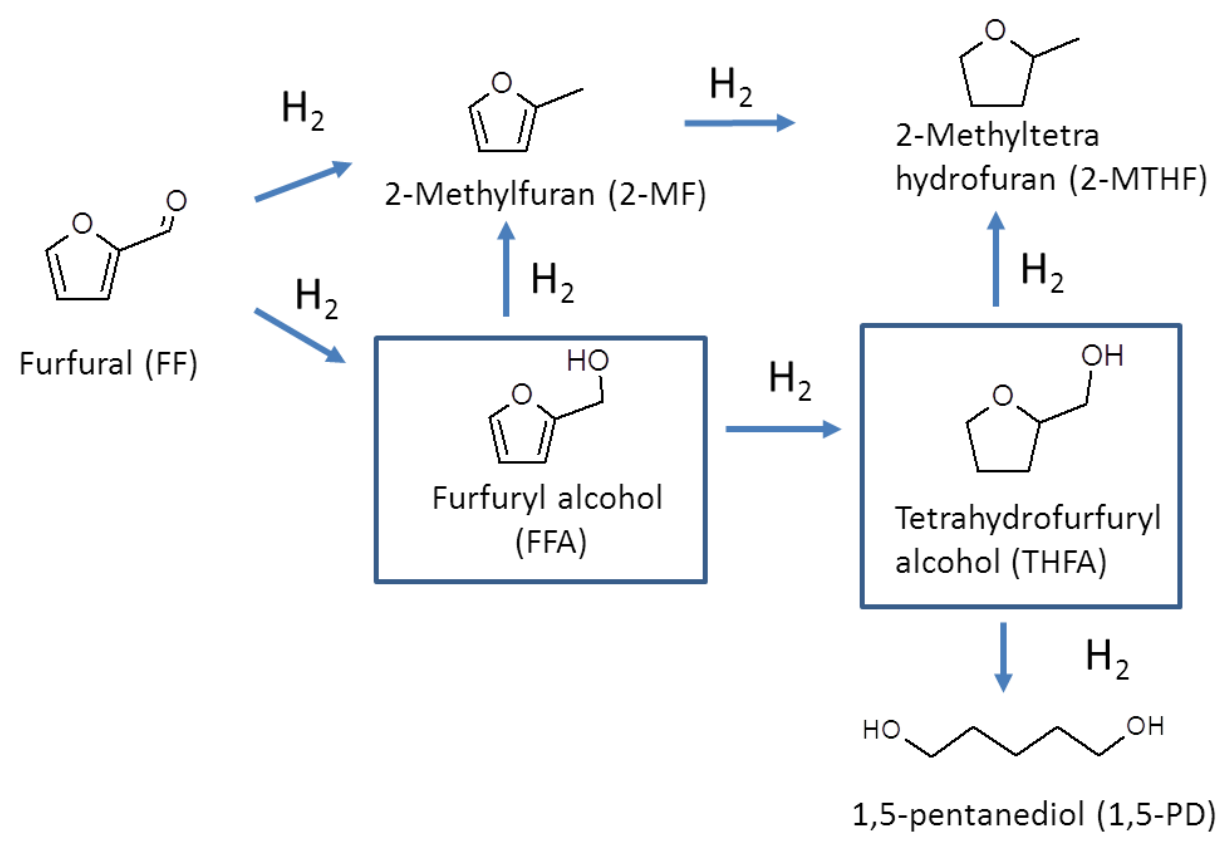

Scheme 3. Reaction pathway for the hydrogenation of furfural.

Table 4 summarises the results obtained showing the total FF Conversion $(C)$, the selectivity $\left(S_{i}\right)$ to FFA and THFA and the Turnover Frequency $(T O F)$ calculated as:

$$
\begin{array}{ll}
C(\%)=\frac{\sum C_{P}}{\sum C_{P}+C_{R}^{u n}} \times 100 & S_{i}(\%)=\frac{C_{i}}{\sum C_{P}} \times 100 \\
\text { TOF }=\frac{\text { mol reactant } \times C(\%)}{\text { mol metal } \times \text { time }(h)} &
\end{array}
$$

where $C_{i}$ stands for the concentration of each product, $\Sigma C_{P}$ is the total concentration of the hydrogenation products and $C_{R}^{u n}$ is the concentration of the unreacted furfural. The evolution of the different species (reactant and products) with time is presented in Figure 7. 
Table 4. Summary of the catalytic test for the hydrogenation of furfural showing Conversion $(\mathrm{C} \%)$, Selectivity $(\mathrm{S} \%)$ to the major products and TOF numbers.

\begin{tabular}{|c|c|c|c|c|c|}
\hline Metal/ SBA-15 & time $(\min )$ & $C(\%)$ & $S(\%)$ FFA & $S(\%)$ THFA & $\operatorname{TOF}\left(\mathrm{h}^{-1}\right)$ \\
\hline \multirow{6}{*}{ Pt RD } & 30 & 33 & 36 & 37 & 14000 \\
\hline & 60 & 61 & 34 & 41 & 13000 \\
\hline & 90 & 70 & 34 & 40 & 10000 \\
\hline & 120 & 71 & 35 & 39 & 7600 \\
\hline & 150 & 73 & 35 & 39 & 6200 \\
\hline & 180 & 73 & 35 & 39 & 5200 \\
\hline $\mathrm{Cu}$ IR & 120 & 5 & 77 & 23 & 460 \\
\hline $\mathrm{Ru} I R$ & 120 & 5 & 79 & 21 & 410 \\
\hline \multirow{6}{*}{$\mathrm{CuPt}(\mathrm{s}) \mathrm{IR}-\mathrm{RD}$} & 30 & 7 & 72 & 28 & 3000 \\
\hline & 60 & 11 & 73 & 27 & 2300 \\
\hline & 90 & 13 & 75 & 25 & 1900 \\
\hline & 120 & 15 & 74 & 26 & 1600 \\
\hline & 150 & 16 & 72 & 28 & 1300 \\
\hline & 180 & 19 & 74 & 26 & 1400 \\
\hline \multirow{6}{*}{ RuPt(s) IR-RD } & 30 & 21 & 64 & 22 & 10000 \\
\hline & 60 & 52 & 50 & 28 & 12000 \\
\hline & 90 & 60 & 53 & 26 & 9600 \\
\hline & 120 & 66 & 54 & 26 & 7900 \\
\hline & 150 & 67 & 54 & 25 & 6400 \\
\hline & 180 & 69 & 55 & 26 & 5500 \\
\hline \multirow{6}{*}{$\mathrm{PtRu}(\mathrm{s}) \mathrm{RD}-\mathrm{RD}$} & 30 & 13 & 61 & 39 & 6400 \\
\hline & 60 & 21 & 88 & 12 & 5300 \\
\hline & 90 & 27 & 93 & 7 & 4500 \\
\hline & 120 & 30 & 94 & 6 & 3700 \\
\hline & 150 & 33 & 95 & 5 & 3300 \\
\hline & 180 & 37 & 95 & 5 & 3000 \\
\hline
\end{tabular}




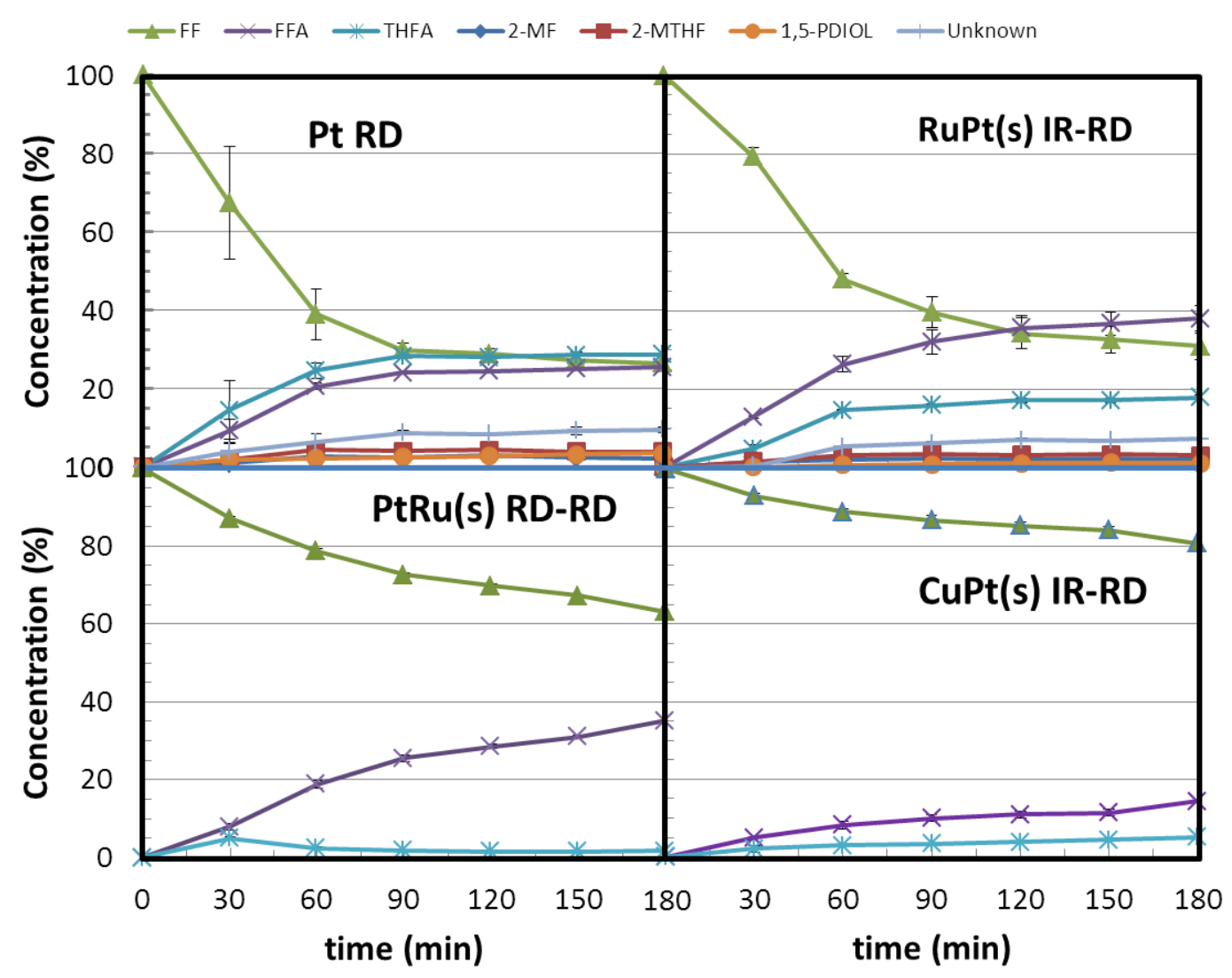

Figure 7. Concentration of reactant and products versus time for the hydrogenation of furfural using the different metal/SBA-15 catalysts prepared in $\mathrm{scCO}_{2}$.

At these conditions, hydrogenation of furfural was not catalysed by the Ru and $\mathrm{Cu} / \mathrm{SBA}-15$ materials prepared in $\mathrm{scCO}_{2}$ and maximum conversions of $5 \%$ were obtained in both cases after 2 hours. On the contrary Pt/SBA-15 was more active in this reaction leading to conversions close to $70 \%$ at 1.5 hours. In this case the major hydrogenation products were FFA and THFA in a molar ratio close to $1: 1$.

When the bimetallic compounds were used, the activity and selectivity changed. The bimetallic catalysts were less active but much more selective to furfuryl alcohol than the Pt catalyst. Furthermore, addition of $\mathrm{Ru}$ or $\mathrm{Cu}$ to $\mathrm{Pt}$, reduced the cost of the catalyst. 
The RuPt(s)/SBA-15 and PtRu(s)/SBA-15 catalysts led to slightly lower conversions of ca. 70 and $40 \%$ at 3 hours, respectively. Both, $\mathrm{RuPt}(\mathrm{s})$ and $\mathrm{PtRu}(\mathrm{s})$ bimetallic materials were selective to FFA. The $\mathrm{CuPt}(\mathrm{s}) / \mathrm{SBA}-15$ catalyst was also selective to FFA, but conversion was very low. In the case of the $\mathrm{PtRu}(\mathrm{s}) / \mathrm{SBA}-15$ catalysts, FFA was practically the only product detected. On the contrary, the $\operatorname{RuPt}(\mathrm{s}) / \mathrm{SBA}-15$ material led to FFA and THFA in a 2:1 molar ratio. These differences can be related to the different Ru content of the samples, which is slightly lower in the PtRu(s) sample (40\% mol). The different selectivity may be also related to the different particle size, which is much larger in the PtRu(s) sample. These results would also support a core-shell structure in the $\mathrm{RuPt}(\mathrm{s}) / \mathrm{SBA}-15$ catalyst, promoted by the low temperature employed in the deposition of $\mathrm{Pt}\left(80^{\circ} \mathrm{C}\right)$ on the $\mathrm{Ru}$ seed. Besides the mild reaction temperature employed in the catalytic tests, the conversion and yield of the PtRu catalysts to FFA were very high. Furthermore only in the Pt and RuPt samples, 2-MF, 2-MTHF and 1,5-PD were also detected along with a small amount of unknown substances, probably due to the much larger activity of these catalysts.

TOF numbers and selectivities to FFA obtained at conversions of ca. $20 \%$ for the different catalysts are compared in Figure 8. Selectivity to FFA varied from 50 to $88 \%$, being maximum for the $\mathrm{PtRu}(\mathrm{s})$ sample, whilst TOFs ranged from 13000 to 1400 from $\mathrm{Pt}$ to the $\mathrm{CuPt}(\mathrm{s})$ catalyst, respectively. The low activity of the CuPt catalyst may be due to the low reduction temperature. 


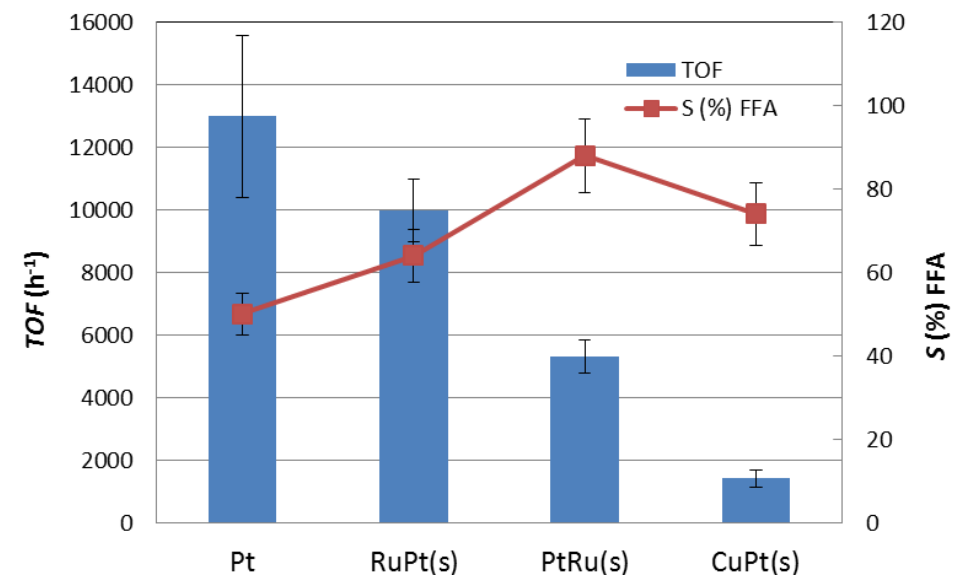

Figure 8. Comparison of TOF and $S(\%)$ to FFA for the different catalysts at $C(\%) c a$. $20 \%$.

The differences found between the PtRu and RuPt samples prepared by sequential deposition show how the order of deposition and the reduction methodology may determine the activity and selectivity of the catalyst due to the different size and structure of the metal particles. Besides these differences, the $\mathrm{PtRu}(\mathrm{s})$ and $\mathrm{RuPt}(\mathrm{s}) / \mathrm{SBA}-15$ catalysts prepared in $\mathrm{scCO}_{2}$ showed very similar yields to furfuryl alcohol.

\section{CONCLUSIONS}

PtRu and PtCu bimetallic NPs were deposited homogeneously on mesoporous $\mathrm{SiO}_{2} \mathrm{SBA}-$ 15 using the SCFD method. The effect that the reduction methodology has on the chemical composition, structure of the bimetallic material and their catalytic properties was addressed for the first time.

Bimetallic NPs were homogeneously distributed throughout the support. Particles were confined to the mesopores of the SBA-15 and, in some cases, became rods. With respect to the methodology, NPs deposited by reactive deposition grew generally larger than those 
obtained by impregnation/reduction. Pt deposited preferentially, when the simultaneous deposition was used. Using the sequential deposition of the metals, depositing $\mathrm{Ru}$ or $\mathrm{Cu}$ in the first place, followed by Pt deposition, a composition close to the stoichiometric one was achieved. STEM data for the PtRu(s) sample prepared by sequential deposition suggested the formation of an alloy. For the other catalyst the analysis could not be performed. The SCFD proved to be a very versatile technique to deposit bimetallic NPs.

These materials were active for the hydrogenation of furfural in $\mathrm{scCO}_{2}$ at very mild temperatures making the process sustainable. $\mathrm{Cu}$ and $\mathrm{Ru}$ catalysts were not active in the hydrogenation of furfural at the chosen conditions. Addition of $\mathrm{Ru}$ or $\mathrm{Cu}$ to $\mathrm{Pt}$, reduces the cost of the catalyst and changes the catalytic activity of the materials. The bimetallic catalysts were less active but much more selective to furfuryl alcohol than the Pt catalyst. Among the materials tested, the $\operatorname{PtRu}(\mathrm{s})$ and $\operatorname{RuPt}(\mathrm{s}) / \mathrm{SBA}-15$ catalyst showed the highest yield to furfuryl alcohol.

In conclusion, the paper demonstrates the efficient utilization of $\mathrm{CO}_{2}$ in both the catalyst preparation and the catalytic reaction. Using more sustainable technologies and conditions, better catalysts can be produced.

\section{ACKNOWLEDGEMENTS}

We gratefully acknowledge the financial support of the Spanish Ministry of Economy and Competitiveness (MINECO), research project CTQ2013-41781-P. We also thank "ICTSCentro Nacional de Microscopía Electrónica", "Centro de Rayos X and "CAI Técnicas Geológicas" at Universidad Complutense de Madrid (UCM) for technical assistance. We 
thank Prof. C. Pando at UCM and Drs. M.J. Franco and O. de la Torre at CEPSA for helpful discussion.

\section{BIBLIOGRAPHY}

[1] G.D. Yadav, M.L. Kantam, B.M. Bhanage, B. Subramaniam, Advances in Catalysis for Sustainable Development Special Issue, ACS Sustainable Chem. Eng. 5(5) (2017) 35973597.

[2] A.K. Singh, Q. Xu, Synergistic Catalysis over Bimetallic Alloy Nanoparticles, Chemcatchem 5(3) (2013) 652-676.

[3] C. Louis, Chemical Preparation of Supported Bimetallic Catalysts. Gold-Based Bimetallic, a Case Study, Catalysts 6(110) (2016).

[4] R. Martínez-Guerrero , A. Hernández-Gordillo, V. Santes, J.R. Vargas-García, J. Escobar, L. Díaz-García, L. Díaz-Barriga-, V. Garibay-Febles, Monometallic Pd and Pt and Bimetallic $\mathrm{Pd}-\mathrm{Pt} / \mathrm{Al}_{2} \mathrm{O}_{3}-\mathrm{TiO}_{2}$ for the HDS of DBT: Effect of the Pd and Pt Incorporation Method, J. Chem. 2014 (2014) 10.

[5] W. Yu, M.D. Porosoff, J.G. Chen, Review of Pt-Based Bimetallic Catalysis: From Model Surfaces to Supported Catalysts, Chem. Rev. 112(11) (2012) 5780-5817.

[6] W. Diao, J.M.M. Tengco, J.R. Regalbuto, J.R. Monnier, Preparation and Characterization of Pt-Ru Bimetallic Catalysts Synthesized by Electroless Deposition Methods, ACS Catal. 5(9) (2015) 5123-5134.

[7] N.N. Kariuki, X. Wang, J.R. Mawdsley, M.S. Ferrandon, S.G. Niyogi, J.T. Vaughey, D.J. Myers, Colloidal Synthesis and Characterization of Carbon-Supported $\mathrm{Pd}-\mathrm{Cu}$ Nanoparticle Oxygen Reduction Electrocatalysts, Chem. Mater. 22(14) (2010) 4144-4152.

[8] B.A. Cheney, J.A. Lauterbach, J.G.G. Chen, Reverse micelle synthesis and characterization of supported $\mathrm{Pt} / \mathrm{Ni}$ bimetallic catalysts on gamma- $\mathrm{Al}_{2} \mathrm{O}_{3}$, Appl. Catal. AGen. 394(1-2) (2011) 41-47.

[9] B.D. Chandler, A.B. Schabel, C.F. Blanford, L.H. Pignolet, Preparation and characterization of supported bimetallic Pt-Au particle catalysts from molecular cluster and chloride salt precursors, J. Catal. 187(2) (1999) 367-384.

[10] T.D. Thanh, J. Balamurugan, S.H. Lee, N.H. Kim, J.H. Lee, Novel porous goldpalladium nanoalloy network-supported graphene as an advanced catalyst for non-enzymatic hydrogen peroxide sensing, Biosens. Bioelectron. 85 (2016) 669-678. 
[11] J.M. Campelo, D. Luna, R. Luque, J.M. Marinas, A.A. Romero, Sustainable Preparation of Supported Metal Nanoparticles and Their Applications in Catalysis, ChemSusChem 2(1) (2009) 18-45.

[12] Y. Zhang, C. Erkey, Preparation of supported metallic nanoparticles using supercritical fluids: A review, J. Supercrit. Fluids 38(2) (2006) 252-267.

[13] S.E. Bozbag, D. Sanli, C. Erkey, Synthesis of nanostructured materials using supercritical CO2: Part II. Chemical transformations, J. Mater. Sci. 47(8) (2012) 3469-3492.

[14] S.E. Bozbag, C. Erkey, Supercritical deposition: Current status and perspectives for the preparation of supported metal nanostructures, J. Supercrit. Fluids 96 (2015) 298-312.

[15] S. Wolff, M. Crone, T. Muller, M. Enders, S. Bräse, M. Türk, Preparation of supported Pt nanoparticles by supercritical fluid reactive deposition: Influence of precursor, substrate and pressure on product properties, J. Supercrit. Fluids 95 (2014) 588-596.

[16] O. Pascu, B. Cacciuttolo, S. Marre, M. Pucheault, C. Aymonier, ScCO2 assisted preparation of supported metal NPs. Application to catalyst design, J. Supercrit. Fluids 105 (2015) 84-91.

[17] Y. Qiao, N. Said, M. Rauser, K. Yan, F. Qin, N. Theyssen, W. Leitner, Preparation of SBA-15 supported Pt/Pd bimetallic catalysts using supercritical fluid reactive deposition: how do solvent effects during material synthesis affect catalytic properties?, Green Chem. 19(4) (2017) 977-986.

[18] G. An, P. Yu, L. Mao, Z. Sun, Z. Liu, S. Miao, Z. Miao, K. Ding, Synthesis of $\mathrm{PtRu} /$ carbon nanotube composites in supercritical fluid and their application as an electrocatalyst for direct methanol fuel cells, Carbon 45(3) (2007) 536-542.

[19] Y.H. Lin, X.L. Cui, C.H. Yen, C.M. Wai, PtRu/carbon nanotube nanocomposite synthesized in supercritical fluid: A novel electrocatalyst for direct methanol fuel cells, Langmuir 21(24) (2005) 11474-11479.

[20] J. Zhao, H. Xue, L. Zhang, J. Yu, H. Hu, Decoration of ultrafine platinum-ruthenium particles on functionalized graphene sheets in supercritical fluid and their electrocatalytic property, J. Nanopart. Res. 14:935 (2012).

[21] S. Lang, M. Tuerk, B. Kraushaar-Czarnetzki, Novel PtCuO/CeO2/alpha-Al2O3 sponge catalysts for the preferential oxidation of $\mathrm{CO}$ (PROX) prepared by means of supercritical fluid reactive deposition (SFRD), J. Catal. 286 (2012) 78-87.

[22] G.I. Garrido, F.C. Patcas, G. Upper, M. Türk, S. Yilmaz, B. Kraushaar-Czarnetzki, Supercritical deposition of Pt on $\mathrm{SnO}_{2}$-coated $\mathrm{Al}_{2} \mathrm{O}_{3}$ foams: Phase behaviour and catalytic performance, Appl. Catal. A-Gen. 338(1) (2008) 58-65. 
[23] S. Müller, M. Türk, Production of supported gold and gold-silver nanoparticles by supercritical fluid reactive deposition: Effect of substrate properties, J. Supercrit. Fluids 96 (2015) 287-297.

[24] R. Mariscal, P. Maireles-Torres, M. Ojeda, I. Sadaba, M. Lopez Granados, Furfural: a renewable and versatile platform molecule for the synthesis of chemicals and fuels, Energy Environ. Sci. 9(4) (2016) 1144-1189.

[25] N.S. Biradar, A.A. Hengne, S.N. Birajdar, R. Swami, C.V. Rode, Tailoring the Product Distribution with Batch and Continuous Process Options in Catalytic Hydrogenation of Furfural, Org. Process Res. Dev. 18(11) (2014) 1434-1442.

[26] L.-J. Liu, H.-M. Guo, B. Xue, H. Lou, M. Chen, Hydrogenation in supercritical conditions catalyzed by palladium supported on modified activated carbon, Rsc Adv. 5(82) (2015) 66704-66710.

[27] J.G. Stevens, R.A. Bourne, M.V. Twigg, M. Poliakoff, Real-Time Product Switching Using a Twin Catalyst System for the Hydrogenation of Furfural in Supercritical $\mathrm{CO}_{2}$, Angew. Chem. Int. Ed. 49(47) (2010) 8856-8859.

[28] D. Zhao, Q. Huo, J. Feng, B.F. Chmelka, G.D. Stucky, Nonionic Triblock and Star Diblock Copolymer and Oligomeric Surfactant Syntheses of Highly Ordered, Hydrothermally Stable, Mesoporous Silica Structures, JACS 136(29) (2014) 10546-10546.

[29] D.Y. Zhao, Q.S. Huo, J.L. Feng, B.F. Chmelka, G.D. Stucky, Nonionic triblock and star diblock copolymer and oligomeric surfactant syntheses of highly ordered, hydrothermally stable, mesoporous silica structures, JACS 120(24) (1998) 6024-6036.

[30] G.I. Garrido, F.C. Patcas, G. Upper, M. Türk, S. Yilmaz, B. Kraushaar-Czarnezki, Supercritical deposition of $\mathrm{Pt}$ on $\mathrm{SnO}_{2}$-coated $\mathrm{Al}_{2} \mathrm{O}_{3}$ foams: Phase behaviour and catalytic performance, Appl. Catal., A 338(1-2) (2008) 58-65.

[31] J. Morere, M.J. Torralvo, C. Pando, J.A.R. Renuncio, A. Cabañas, Supercritical fluid deposition of $\mathrm{Ru}$ nanoparticles onto $\mathrm{SiO}_{2} \mathrm{SBA}-15$ as a sustainable method to prepare selective hydrogenation catalysts, RSC Adv. 5 (2015) 38880-38891.

[32] J. Morere, E. Sánchez-Miguel, M.J. Tenorio, C. Pando, A. Cabañas, Supercritical Fluid Preparation of $\mathrm{Pt}, \mathrm{Ru}$ and $\mathrm{Ni} /$ graphene nanocomposites and their application as selective catalysts in the partial hydrogenation of limonene, J. Supercrit. Fluids 120 ( 2017) 7-17.

[33] M. Türk, M. Crone, G. Upper, Effect of gas pressure on the phase behaviour of organometallic compounds, J. Supercrit. Fluids 58(1) (2011) 1-6.

[34] G. Raykhtsaum, Platinum Alloys: A Selective Review of the Available Literature, Platinum Met. Rev. 57(3) (2013) 202-213. 
[35] G.A. Camara, M.J. Giz, V.A. Paganin, E.A. Ticianelli, Correlation of electrochemical and physical properties of PtRu alloy electrocatalysts for PEM fuel cells, J. Electroanal. Chem. 537(1-2) (2002) 21-29.

[36] J. Solla-Gullon, F.J. Vidal-Iglesias, V. Montiel, A. Aldaz, Electrochemical characterization of platinum-ruthenium nanoparticles prepared by water-in-oil microemulsion, Electrochim. Acta 49(28) (2004) 5079-5088.

[37] T. Abe, B. Sundman, H. Onodera, Thermodynamic assessment of the Cu-Pt system, J. Phase Equilib. Diffus. 27(1) (2006) 5-13.

[38] M.S. Nashner, A.I. Frenkel, D.L. Adler, J.R. Shapley, R.G. Nuzzo, Structural Characterization of Carbon-Supported Platinum-Ruthenium Nanoparticles from the Molecular Cluster Precursor PtRu5C(CO)16, JACS 119(33) (1997) 7760-7771.

[39] M.J. Tenorio, J. Morère, C. Carnerero, M.J. Torralvo, C. Pando, A. Cabañas, Thiol group functionalization of mesoporous $\mathrm{SiO} 2 \mathrm{SBA}-15$ using supercritical $\mathrm{CO} 2$, Microporous and Mesoporous Materials 256 (2018) 147-154.

[40] J. Morere, M.J. Tenorio, M.J. Torralvo, C. Pando, J.A.R. Renuncio, A. Cabanas, Deposition of Pd into mesoporous silica SBA-15 using supercritical carbon dioxide, J. Supercrit. Fluids 56(2) (2011) 213-222.

[41] C. Zhang, Q. Lai, J.H. Holles, Bimetallic overlayer catalysts with high selectivity and reactivity for furfural hydrogenation, Catalysis Communications 89 (2017) 77-80.

[42] M.J. Taylor, L.J. Durndell, M.A. Isaacs, C.M.A. Parlett, K. Wilson, A.F. Lee, G. Kyriakou, Highly selective hydrogenation of furfural over supported Pt nanoparticles under mild conditions, Applied Catalysis B: Environmental 180 (2016) 580-585. 


\section{Graphical Abstract}

\section{Green Preparation of PtRu and PtCu/SBA-15 Catalysts using Supercritical $\mathrm{CO}_{2}$}

E. Sánchez-Miguel, M.J. Tenorio, J. Morère and A. Cabañas*

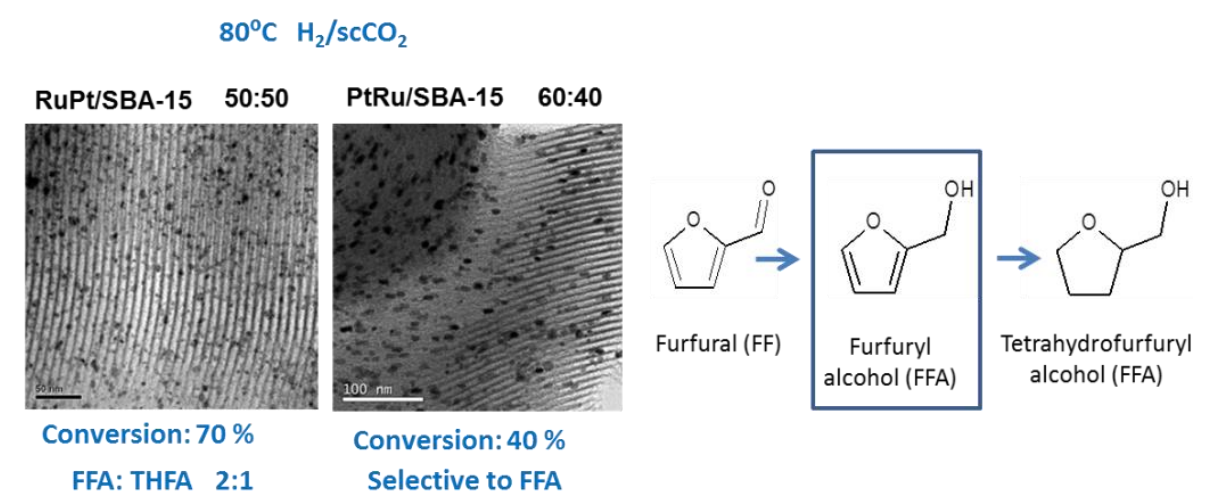




\section{SUPPLEMENTARY INFORMATION}

\section{Green Preparation of PtRu and PtCu/SBA-15 Catalysts using Supercritical $\mathrm{CO}_{2}$}

E. Sánchez-Miguel, M.J. Tenorio, J. Morère and A. Cabañas*

Departamento de Química-Física I, Universidad Complutense de Madrid, 28040 Madrid.

SPAIN 
Selected $\mathrm{PtCu}$ and $\mathrm{CuPt}$ samples were annealed at 600 and $900^{\circ} \mathrm{C}$ in $\mathrm{H}_{2} / \mathrm{N}_{2}$ in a tubular furnace for 3 hours. Peak position of the (111) reflection for cubic Pt shifted slightly to larger $2 \theta$ values after annealing. Shifting was larger for the $\mathrm{CuPt}(\mathrm{s})$ IR-RD sample in which $\mathrm{Pt}$ was deposited on a $\mathrm{Cu}$ seed at $80^{\circ} \mathrm{C}$. The low temperature employed in the Pt deposition may have produced a core-shell structure. Alloying of the metals was promoted with annealing.
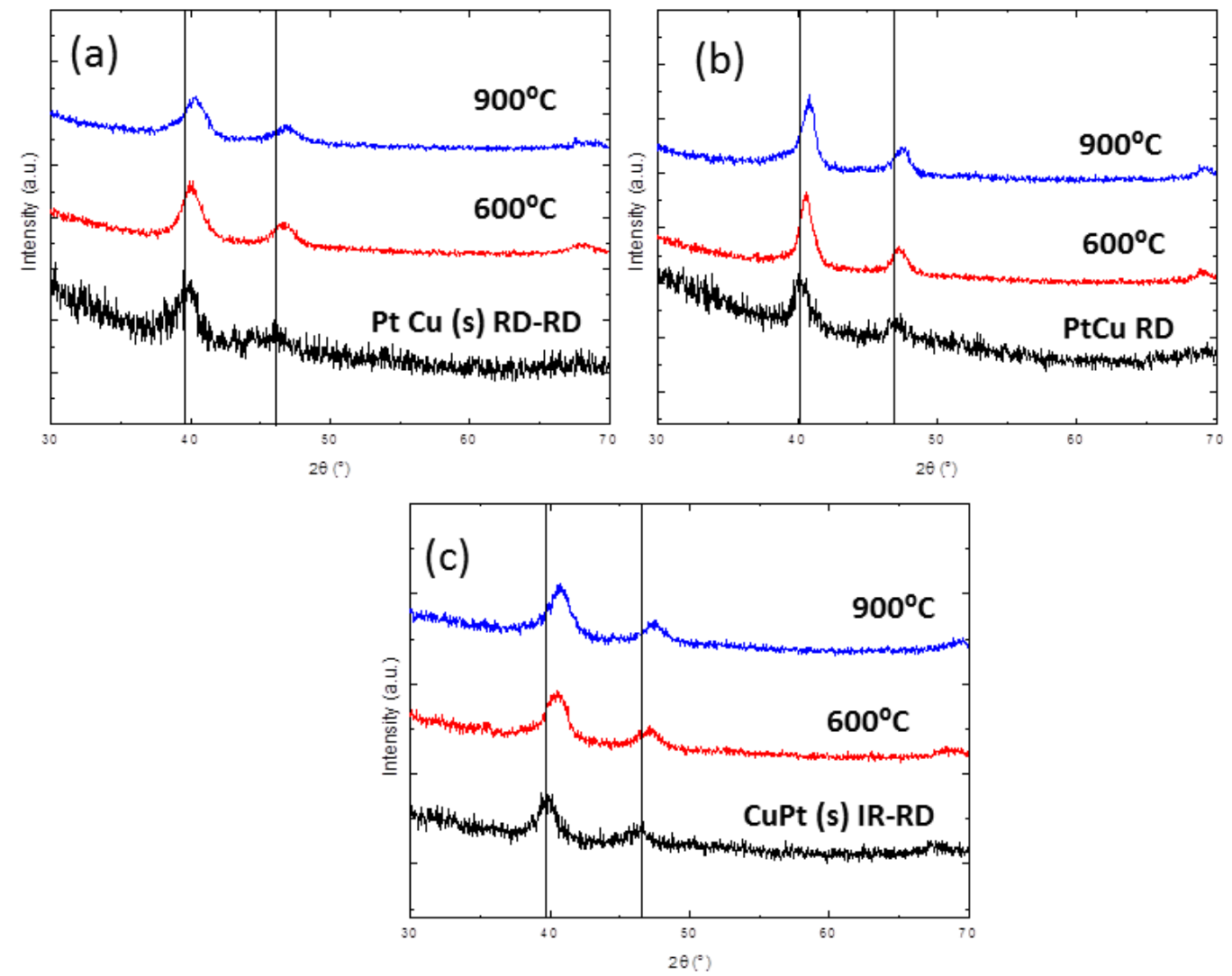

Figure S1. XRD patterns of selected $\mathrm{PtCu}$ bimetallic samples prepared in $\mathrm{scCO}_{2}$

$\mathrm{PtCu}$ (s) RD-RD, (b) PtCu RD and (c) CuPt(s) IR-RD before and after annealing in $\mathrm{H}_{2} / \mathrm{N}_{2}$ at 600 and $900{ }^{\circ} \mathrm{C}$. 
